\title{
Techno-economic feasibility of fleets of far offshore hydrogen-producing wind energy converters
}

\author{
Aurélien Babarit, Jean-Christophe \\ Gilloteaux, Gaël Clodic, Maxime Duchet \\ LHEEA Lab. \\ Ecole Centrale de Nantes - CNRS \\ 1 rue de la Noë, 44300 Nantes, France \\ Alexandre Simoneau \\ WEREVER \\ 1 rue de la Noë, 44300 Nantes, France
}

\author{
Max F. Platzer \\ AeroHydro R\&T Associates \\ Pebble Beach, \\ CA 93953, USA
}

Abstract

Innovative solutions need to be developed for harvesting wind energy far offshore. They necessarily involve on-board energy storage because grid-connection would be prohibitively expensive. Hydrogen is one of the most promising solutions. However, it is well-known that it is challenging to store and transport hydrogen which may have a critical impact on the delivered hydrogen cost.

In this paper, it is shown that there are vast areas far offshore where wind power is both characterized by high winds and limited seasonal variations. Capturing a fraction of this energy could provide enough energy to cover the forecast global energy demand for 2050. Thus, scenarios are proposed for the exploitation of this resource by fleets of hydrogen-producing wind energy converters sailing autonomously. The scenarios include transportation and distribution of the produced hydrogen.

The delivered hydrogen cost is estimated for the various scenarios in the short term and in the longer term. Cost estimates are derived using technical and economic data available in the literature and assumptions for the cost of electricity available on-board the wind energy converters. In the shorter term, delivered cost estimates are in the range 7.1 to $9.4 € / \mathrm{kg}$ depending on the scenario and the delivery distance. They are based on the assumption of on-board electricity cost at $0.08 € / \mathrm{kWh}$. In the longer term, assuming an on-board electricity cost at $0.04 € . \mathrm{kWh}$, the cost estimates could reduce to 3.5 to $5.7 € / \mathrm{kg}$ which would make the hydrogen competitive on several hydrogen markets without any support mechanism. For the hydrogen to be competitive on all hydrogen markets including the ones with the highest GHG emissions, a carbon tax of approximately $200 € / \mathrm{kg}$ would be required.

Keywords: Offshore wind energy, sailing wind turbines, energy ship, hydrogen, techno-economic analysis

\section{Introduction}

By the end of 2016, the total installed capacity of offshore wind energy in Europe was 12.6 GW, corresponding to approx. 3,600 grid-connected turbines [1]. All of them were bottom-fixed wind turbines. According to the European Energy Agency [2], the constrained technical potential for bottom-fixed offshore wind energy (water depth less than $50 \mathrm{~m}$ ) is 3,500 TWh per year by 2030. It corresponds to $16 \%$ of the forecasted 2030 energy demand in the European Union $(21,000 \mathrm{TWh} / \mathrm{y})$ in the reference scenario in [3]. Moving farther offshore is thus necessary to increase the offshore wind technical potential.

Floating wind turbines have been developed (e.g. [4],[5]). They address the challenge of deeper water. The world's first floating wind farm is expected to start producing by the end of 2017 [6]. The offshore wind technical potential available nearshore $(<90 \mathrm{~km})$ and in intermediate water depth $(<200 \mathrm{~m})$ is in order of 180,000 TWh/y according to[7], which is less than the forecasted energy 
demand in 2050 in the reference scenario of [8] (240,000 TWh/y). To further increase the technical potential, wind energy conversion technologies which can be deployed far offshore (hundreds to thousands of $\mathrm{km}$ from shore) must be developed. There, it is no longer feasible from an economic perspective to use grid-connected wind turbines because grid-connection increases linearly with increasing distance to shore [9]. Other means to transfer the energy from the source of production to the consumer must be considered. It involves energy storage for which many options (compressed air energy storage, batteries, hydrogen, etc.) are available [10].

A remarkable benefit of on-board energy storage for far offshore wind energy converters is that the constraint for the supporting platform to be stationary is removed. In other words, the system can be mobile. Being mobile has two advantages. Firstly, it removes the need for moorings $\&$ anchors which has a significant impact on capital expenditures (CAPEX). According to [5], moorings and anchors (including installation) account for approximately 20\% of CAPEX of typical floating offshore wind projects. Secondly, the system being mobile, it may sail to the resource which may lead to greater capacity factors. Note that capacity factor for offshore wind turbines is already rather high, being in average approximately $40 \%$ according to [5]. Still, for harvesting the far offshore wind energy resource, it appears that mobile wind energy conversion systems may represent a cost competitive alternative to floating offshore wind turbines.

To our knowledge, there has been only a small number of technology proposals for harvesting wind energy far in the ocean with mobile systems [11][12][13][14][15][16][17][18]. These systems implement quite diverse technologies, see Figure 1. However, they can broadly be classified in two categories: sailing wind turbines and energy ships. Sailing wind turbines make use of conventional wind turbines [14]. They can be vertical-axis wind turbines [18]. In these concepts, wind energy is directly converted into electricity. In energy ships, wind energy is primarily used to propel the ship. Electricity generation is obtained through a water turbine attached to the hull of ship. For wind propulsion, it has been proposed to implement conventional sails [11][13][16], kites [15][18], rigid wing sails [16] or Flettner rotors [17]. Regarding the hull shape, catamarans are used in most proposals. One exception is the proposal of [14] which uses a very large proa-shaped hull. Obviously, other hull shapes are available such as monohulls, trimarans etc.

A common feature of all the aforementioned technology proposals is the use of hydrogen for the storage of the harvested energy. Note that in [15], it is proposed to further convert the produced hydrogen into methanol or to use it to convert carbon dioxide into storable forms of liquid for Carbon Capture and Storage (CCS). The concept of using renewable energy sources or renewable feedstock for hydrogen production or other high value chemicals is widely spread nowadays. Renewable hydrogen production can be achieved from biomass [19][20], from solar energy through photolytic processes [21][22], or from renewable electricity through water electrolysis (e.g. [23]). Pilot plants for hydrogen production from renewable electricity have been reviewed in [24]. Techno-economic studies are available for hydrogen production from wind farms, e.g. [25][26].

To our knowledge, only a few references discuss the techno-economic potential of one or the other of concepts of energy ships or sailing wind turbines. Promising cost estimates for LH2 (Liquid hydrogen) have been obtained in [27] for two particular designs of an energy ship implementing a large kite sailing at high altitude. However, some of their economic and technical data is questionable (for example: 50US $\$ \mathrm{~kW}$ for the electrolyser). In [15], it is shown that fleets of such energy ships deployed in the Southern oceans and the North of the Pacific Ocean could provide 47 TW of average power output which corresponds to $170 \%$ of the forecasted global energy demand for 2050 . Thus, this study indicates that there is a huge potential of renewable energy available in the winds over the oceans. Recently, in [28][29] a techno-economic study of optimal ocean wind energy converters was published using a multi-pole systems analysis. In [28] the minimal levelized cost of hydrogen was determined to be $13.9 € / \mathrm{kg}$, whereas in ][29] it was claimed that the operation of small sailboats could produce a profit at a hydrogen price of $10 € / \mathrm{kg}$. 


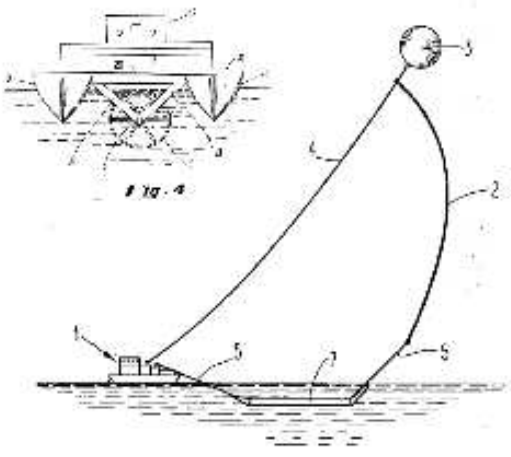

Salomon (1982)

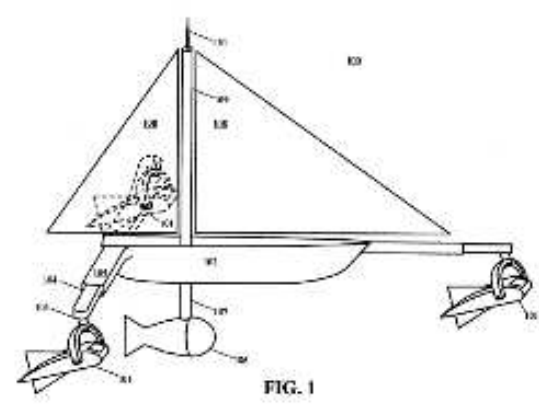

Gizara (2007)

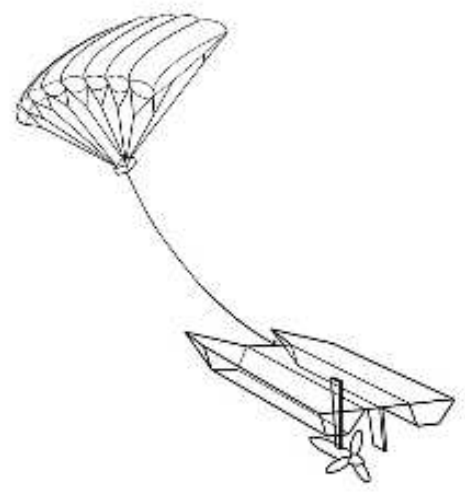

Kim \& Park (2010)

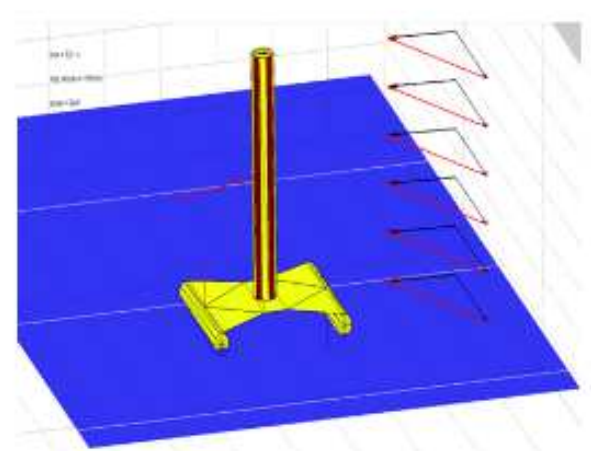

Gilloteaux \& Babarit (2017)

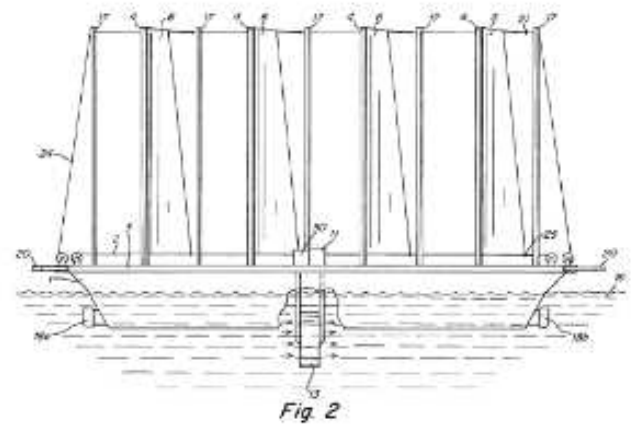

Meller (2006)

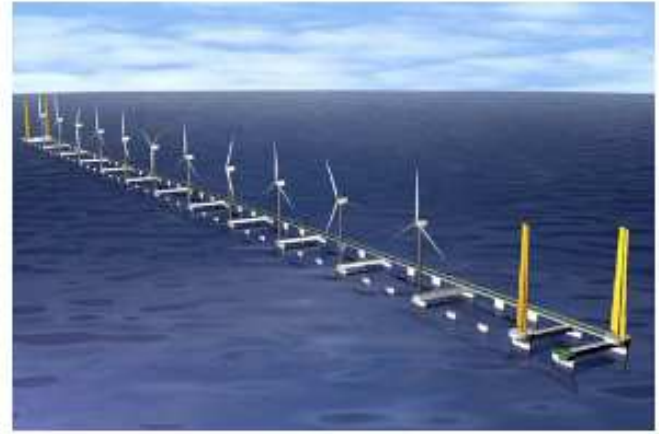

Tsujimoto et al. (2009)

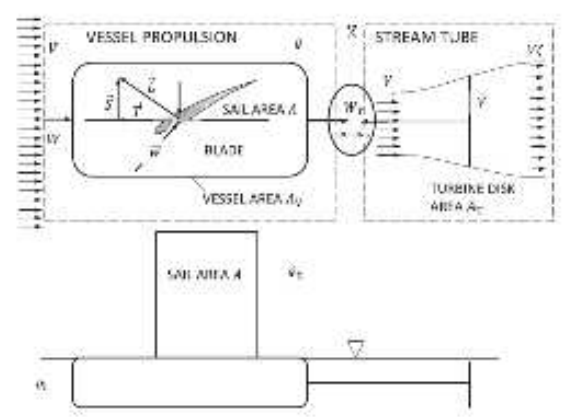

Pelz, Holz \& Platzer (2016)

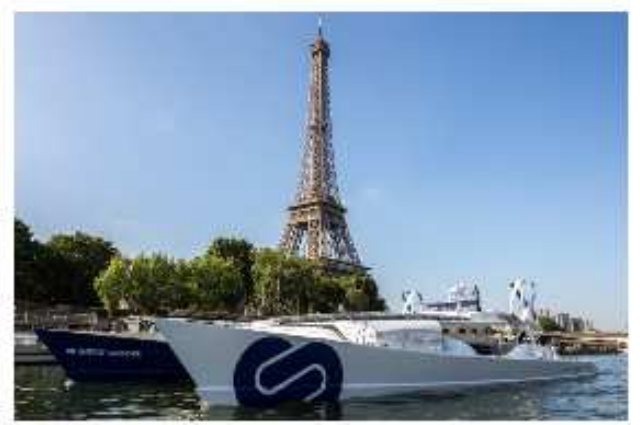

www.energy-observer.org

Figure 1 Pictures of technology proposals for far harvesting wind energy far in the ocean with mobile systems. 
Thus, it appears that no comprehensive study of the far offshore wind energy potential is available in the literature. Also, all technology proposals suggest converting wind energy to hydrogen but they don't discuss the other options nor the hydrogen market requirements. Finally, it is wellknown that hydrogen is a challenging fuel to store and transport which may have a significant impact on the cost of hydrogen when delivered to the end-user. Therefore, the aim of this paper is to address these knowledge gaps.

\section{The far offshore wind energy resource}

The global wind energy resource is estimated to $15,000,000 \mathrm{TWh} / \mathrm{y}$ [30]. This estimate takes into account wind energy from the lower to the upper atmosphere. According to [7], the onshore wind energy resource in the lower atmosphere is $1,100,000 \mathrm{TWh} / \mathrm{y}$. It is the wind energy resource that can be harvested using conventional wind turbines. Note that there are attempts to develop new technologies for harvesting the wind energy resource at higher altitudes. An example is the energy kite developed by the Makani company [31].

Regarding offshore, the nearshore $(<90 \mathrm{~km})$ wind energy technical potential in the lower atmosphere and in intermediate water depth $(<200 \mathrm{~m})$ is $180,000 \mathrm{TWh} / \mathrm{y}$ according to [7]. Curiously, it seems that there has been no assessment of the global offshore wind energy potential in the lower atmosphere (including the far offshore). Since the oceans cover $2 / 3$ of the planet surface, a rough estimate of this potential is twice the onshore potential. It leads to $2,200,000 \mathrm{TWh} / \mathrm{y}$. It corresponds to 12 times the near shore wind energy resource and more importantly 9 times the 2050 forecasted energy demand $(240,000 \mathrm{TWh} / \mathrm{y}[8])$. It shows that the far offshore wind energy has the potential to cover the global demand.
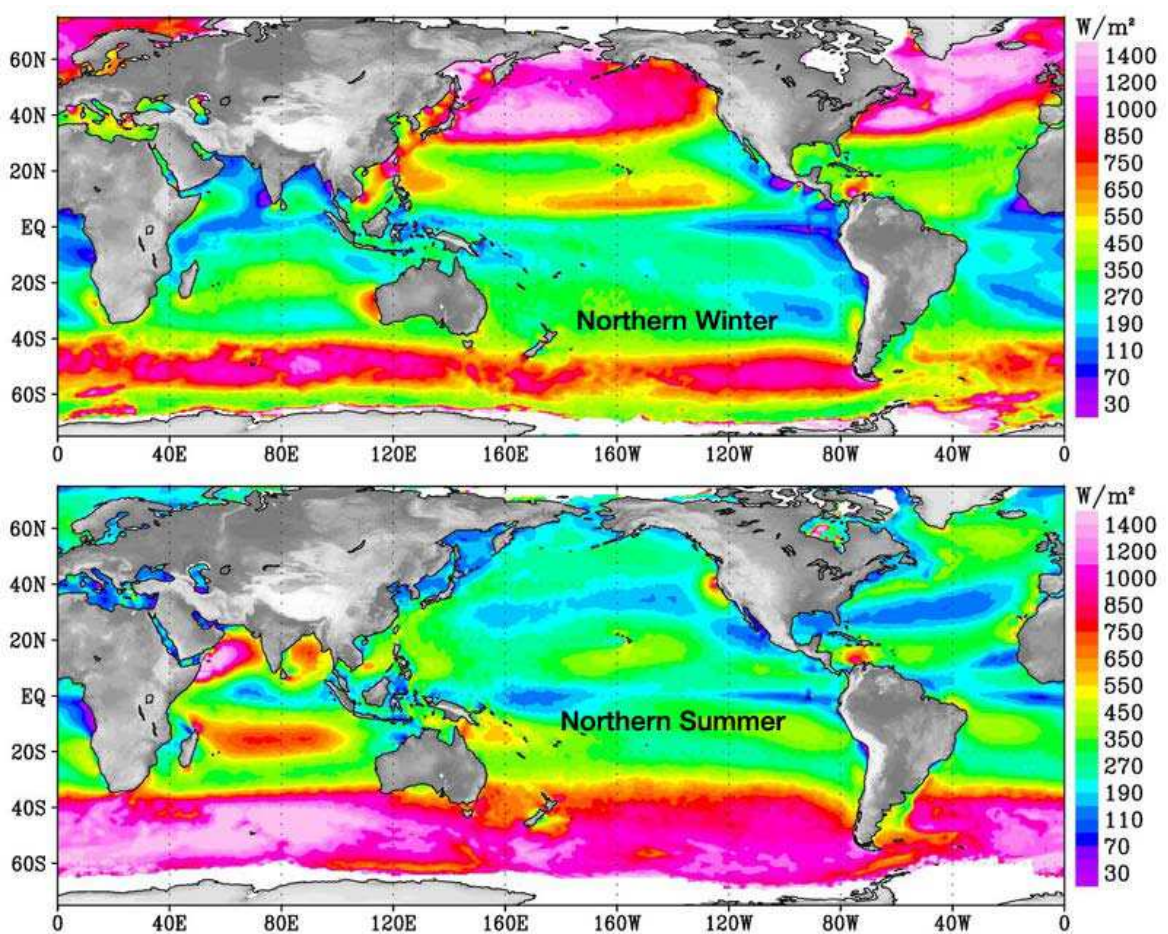

Figure 2 Global wind power distribution. The picture is taken from [32].

In [32], the global wind power distribution over the ocean was computed from satellite measurements. The result is shown in Figure 2. The wind power $P$ is given in watts per square meter of frontal area $\left(\mathrm{W} / \mathrm{m}^{2}\right)$. It is related to the wind speed $U_{10}$ at $10 \mathrm{~m}$ altitude through the relation:

$$
P=\frac{1}{2} \rho U_{10}^{3}
$$


Where $\rho$ is the air density.

In wind energy engineering, the wind resource is classified according to the mean wind speed at hub-height. Class I winds (high wind) correspond to a wind speed at hub-height greater than $8.5 \mathrm{~m} / \mathrm{s}$ [33] which corresponds to a wind power of approximately $350 \mathrm{~W} / \mathrm{m}^{2}$. By combining the data of Figure 2 for the northern summer and winter, offshore areas with class I wind both during the northern summer and northern winter can be identified. They are shown in Figure 3. Note that the data in Figure 2 is for a wind speed at $10 \mathrm{~m}$ altitude. At hub-height (typically $70 \mathrm{~m}$ ), the power density is greater because of the atmospheric boundary layers. Thus, the methodology is expected to be conservative. A refined approach would lead to identification of greater offshore areas with Class I wind.

In any case, the hatched areas in Figure 3 are well suited for deployment of far offshore wind conversion systems for two reasons. Firstly, the energy production is obviously related to the wind power density (the greater the wind, the greater will be the production). Secondly, the wind resource should be as stable as possible all year round to maximize the capacity factor. In [34], it has been shown that, in the UK, the average monthly wind power capacity factor is less than $20 \%$ in July and August whereas it is almost $40 \%$ in January. Therefore, areas with high winds both in winter and summer are required for high capacity factors and high energy production.

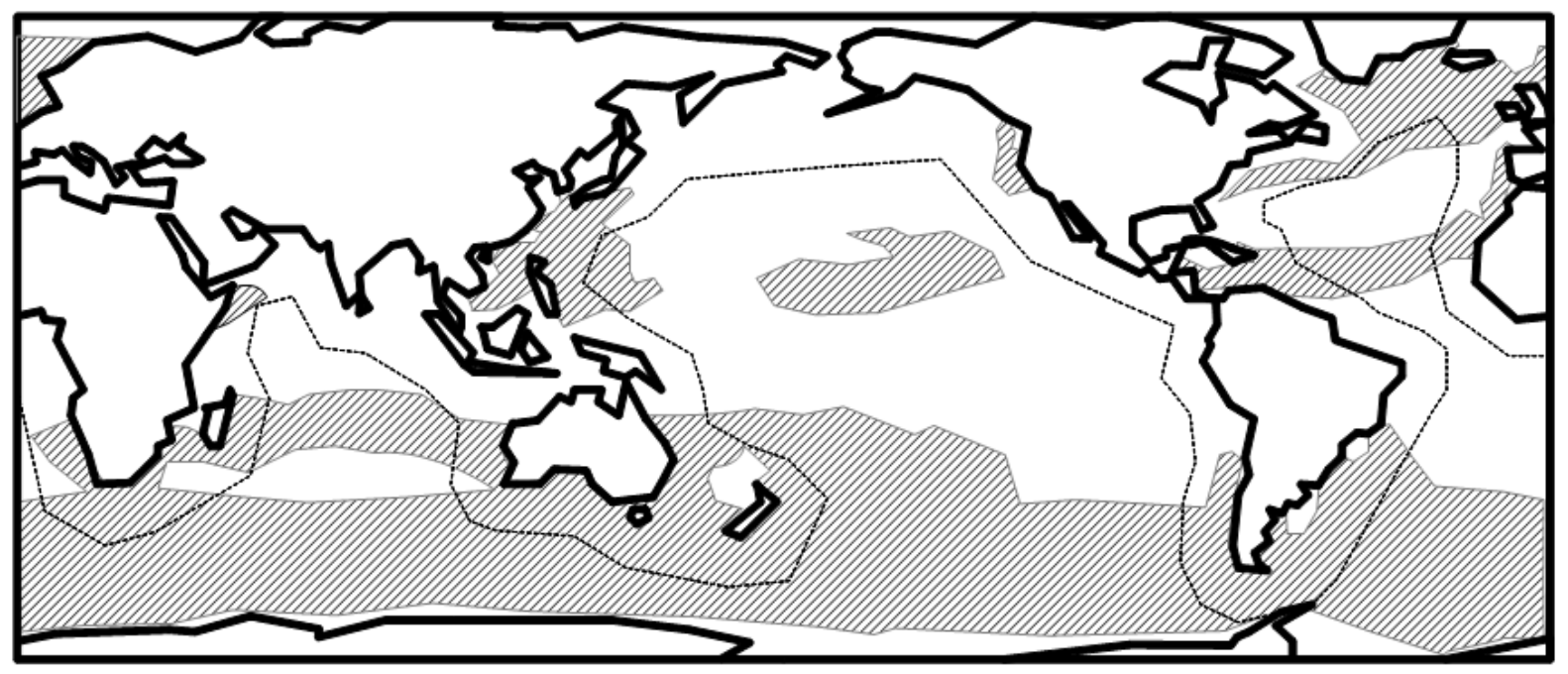

Figure 3 Offshore areas of class I wind during both the northern summer and northern winter. The dashed line indicates a distance of approximately $1,000 \mathrm{~km}$ to shore.

One can see that there are vast areas in the ocean which meet these two requirements. The total surface can be estimated to roughly $140,000,000 \mathrm{~km}^{2}$ which corresponds to $40 \%$ of the global ocean surface. As expected, the north and the south of the Atlantic Ocean, the south of the Indian Ocean and the Pacific Ocean, and the Southern Ocean would be suitable for high capacity factors far offshore wind energy converters. It is more surprising to note that the north of the Pacific Ocean does not meet the requirements. It is because of the low resource during the northern summer. Other significant possible areas are the middle of the Atlantic Ocean from Portugal to Venezuela, an area surrounding the Hawaii islands, an area comprising the South China Sea and part of the West of the Pacific Ocean and an area in the middle of the Indian Ocean from Australia to Madagascar and South Africa. There are also smaller areas with potential close to the West coast of Canada, West coast of South Africa and Namibia, and the coast of Somalia. It is worth noting that several of those areas are rather close to areas with high population density, such as the area in the West Pacific, the areas close to Africa, Central America or Europe. 
In Figure 3, the dashed line indicates a distance of approximately $1,000 \mathrm{~km}$ to shore, corresponding to 1.5 days for a ship sailing at 15 knots. It gives a sense of how far the resource is from shore. The total surface of class I wind in the band $0-1,000 \mathrm{~km}$ from shore can be estimated as roughly $40,000,000 \mathrm{~km}^{2}$. Thus, a good deal of the resource $(30 \%)$ is available at moderate distance from the coast.

Let us further assume that $1 \%$ of the $0-1,000 \mathrm{~km}$ band is exploited by fleets of far offshore wind energy conversion systems. Assuming a rated capacity of $2 \mathrm{MW}, 90 \%$ capacity factor and a density of 1 converter per $\mathrm{km}^{2}$, the converter energy output would be approximately 6,000 TWh which is $2.5 \%$ of the forecasted energy demand in 2050. Starting from the 2050 energy demand, it can be estimated that it would take approximately $15,000,000 \mathrm{~km}^{2}$ to cover all the demand. It corresponds to $10 \%$ of the hatched areas in Figure 3 and thus $4 \%$ of the global ocean surface. Thus, it appears that fleets of far offshore wind energy converters have the potential to make a great contribution to the global energy supply.

\section{Technical options for energy storage}

One major challenge for far offshore wind energy converters is the transportation of the converted wind energy to the consumers. Grid-connection is not possible far offshore because the cost would be too high (grid-connection costs increase linearly with the distance to shore [9]). Therefore, far offshore wind energy converters must include onboard energy storage.

There are many options available for energy storage [10]. They include batteries, compressed air energy storage (CAES), fuel for fuel cells such as hydrogen, etc. In [10], energy storage technologies are compared with respect to power rating and discharge time, storage duration, capital cost, energy and power density, life time and cycle life, and influence on environment. Power rating of modern wind turbines is in the range of $1-10 \mathrm{MW}$. Therefore, let us assume that power rating of far offshore wind converters is in the order of $2 \mathrm{MW}$. Being far offshore, long energy storage duration is required. Indeed, there may be several days to weeks between the time when the energy is produced offshore and the time when it is delivered to the consumer. One week of energy production at a rated power of $2 \mathrm{MW}$ corresponds to approximately $300 \mathrm{MWh}$. It is a considerable amount of energy to store. Therefore, energy storage technologies with high energy density should be considered for for use of the available space onboard.

According to Tables 1 and 2 in [10], the most suitable options are fuel for fuel cells and metalair batteries because they have the highest energy density. In this last table, the higher value of 10,000 $\mathrm{Wh} / \mathrm{kg}$ for the density for fuels is certainly for cryogenic fuels, although it is not clearly mentioned in the text in [10]. Indeed, according to the specifications of cryogenic ISO containers of Worthington industries (see [35]), the gravimetric density of stored liquid hydrogen including storage tank mass is in the order $6,200 \mathrm{Wh} / \mathrm{kg}$. It may be even higher. Hydrogen tanks were developed in the 1950-60s for aircraft for which the gravimetric density was up to $29,000 \mathrm{Wh} / \mathrm{kg}$ [36]. Nevertheless, it is known that the mass of a storage system containing $300 \mathrm{MWh}$ of cryogenic fuel is in order of 50 tons. The lower value of $800 \mathrm{Wh} / \mathrm{kg}$ for the fuel for fuel cells in Table 2 in [10] is believed to correspond to high pressure storage. With current technology, it is expected that the storage mass in high pressure tanks for gaseous fuels is in the order of 200 tons for $300 \mathrm{MWh}$. A similar storage mass is quoted for metal-air batteries.

Li-ion batteries or low-temperature thermal energy storage may also be suitable options although their energy density is at least one order of magnitude smaller than that of fuels for fuel cells or metal-air batteries. With those technologies, the mass a $300 \mathrm{MWh}$ energy storage capacity would be in order of 2,000 tons. Other options which meet the power rating and long storage duration requirements are pumped-hydro storage (PHS), compressed air storage (CAES), flow batteries, leadacid and NiCd batteries. However, their energy density is even lower. For example, the mass of a 300 MWh energy storage system with lead-acid batteries is in order of 10,000 tons. This figure is of the 
same of order as the displacement of the heaviest floating offshore wind turbine ever built (Fukushima Shinpuu, $7 \mathrm{MW}, 10,000$ tons displacement) [4]. Note that in this analysis, solar fuels and high temperature thermal energy storage have been discarded despite their good energy density because they are specific to solar energy storage.

\begin{tabular}{|c|c|c|c|c|}
\hline $\begin{array}{c}\text { Energy storage } \\
\text { system }\end{array}$ & Cryogenic fuels & $\begin{array}{c}\text { Fuels; Metal-air } \\
\text { batteries }\end{array}$ & $\begin{array}{c}\text { Li-ion batteries; low } \\
\text { temperature thermal } \\
\text { energy storage }\end{array}$ & $\begin{array}{c}\text { Pumped-hydro } \\
\text { storage; compressed } \\
\text { air storage; flow } \\
\text { batteries; lead-acid } \\
\text { and NiCd batteries }\end{array}$ \\
\hline $\begin{array}{c}\text { Mass of a 300 MWh } \\
\text { capacity energy } \\
\text { storage system } \\
\text { (approx. 1 week of } \\
\text { production at } 2 \mathrm{MW} \\
\text { rated power) }\end{array}$ & $\sim 50$ tons & $\sim 200$ tons & $\sim 2,000$ tons & $\sim 10,000$ tons \\
\hline
\end{tabular}

Table 1. Comparison of masses of 300 MWh energy storage systems for long duration energy storage

Table 1 summarizes the discussion of the most suitable energy storage systems for far offshore wind energy converters. Eventually, it appears that the most viable options are fuel for fuel cells (including cryogenic fuels) and metal-air batteries. Therefore, it is not surprising that hydrogen was selected in all technology proposals for far offshore wind energy conversion (references [11] to [17]), although none of these references discuss why hydrogen is preferable to other energy storage solutions. In [15], it is also proposed to further convert the produced hydrogen into methanol (another possible fuel for fuel cells) or to use the energy to convert carbon dioxide into storable forms of liquid for Carbon Capture and Storage (CCS).

Still, metal-air batteries are another option for energy storage for far offshore wind energy converters. According to [10], their cycle efficiency is similar to fuel cells (30-50\%) and their technical maturity is slightly less, both being in the development stage. The capital cost of metal-air batteries is reported to be low in the order of 10-60 $\$ / \mathrm{kWh}$. However, their cycle life is limited, in the range of 100-300 cycles according to [10]. Although this is an issue when energy storage is used to mitigate the intermittency of renewable energy sources or for mobility applications, this is less a problem for far offshore wind energy converters assuming that the cycle duration is one week. Indeed, the lifetime would then be almost 4 years assuming an average 200 cycles of cycle life.

In the rest of this paper, hydrogen is selected for further analysis of its techno-economic potential when produced by fleets of far offshore wind energy converters. However, it must be mentioned that other fuels for fuel cells or metal-air batteries are other possibly viable energy storage solutions for far offshore wind energy converters. The analysis of their potential will be performed in future work.

\section{Market opportunities for hydrogen produced by fleets of far offshore wind energy converters}

Over the last decades, hydrogen has received a great deal of attention because it could represent an alternative fuel to fossil fuels - if produced from renewable energy sources. Let us recall that the share of fossil fuels to satisfy the primary energy requirements in the European Union was more than $90 \%$ in 2009 [3]. One third of the final energy demand came from the transport sector [3]. According to [37], "hydrogen seems especially promising (...) as it can contribute to the three most important targets with respect to transportation energy use (...): GHG emissions reduction, energy security and reduction of local air pollution". However, as mentioned by the authors in [37], hydrogen for transportation uses competes with electric vehicles which can offer the same benefits. When their 
study was published in 2009, the global electric car stock was less than 100,000 [38]. This number increased impressively over the last 8 years, reaching 2,000,000 in 2016 (including plug-in hybrid electrical vehicles and battery electric vehicles). Nowadays, there are also fuel-cell cars available commercially (e.g. the Toyota Mirai). However, the global fuel cell cars stock is three orders of magnitude smaller. The competitiveness gap between electric and fossil fuel cars has narrowed thanks to reduction in the battery cost (it decreased by a factor three since 2009). The lack of hydrogen distribution infrastructure is also a greater challenge for fuel cell cars than it is for electric vehicles. Therefore, it may well be that the competition between electric cars and hydrogen fuel cell cars has already been won by the former for the near future. Note that in the longer term, shortage in materials needed for batteries may improve the attractiveness of hydrogen fuel cell cars in comparison to electric cars.

Other mobility applications include fuel-cell forklifts, fuel-cell urban buses, fuel-cell trucks or hydrogen powered airplanes. According to [39], fuel economy results for fuel-cell buses are $40 \%$ to $90 \%$ better than diesel and compressed natural gas buses. In 2016, fuel-cell buses were considered to have reached technology readiness level (TRL) 7, that is full-scale validation in a relevant environment. According to [40], the acceptable hydrogen fuel price for urban bus applications is 4 to 5 $€ / \mathrm{kg}$. However, the development of fuel-cell urban buses suffers from the competition with electric buses. The same applies to fuel-cell trucks. In contrast to trucks and buses, fuel cell forklifts are commercial technologies. There were over 10,000 of them in operations in 2017 [41]. Their advantage over battery-powered forklifts is that they are much quicker to charge [42]. According to [40], the acceptable hydrogen fuel price for fuel-cell forklifts is 6 to $7 € / \mathrm{kg}$.

Regarding liquid hydrogen as an aviation fuel, it was investigated by NACA and the US Air Force in the 1950s [36]. In 1957, three successful flights were made with a B-57 airplane modified to use hydrogen in one engine. It demonstrated the feasibility of using liquid hydrogen in flight for jet propulsion. Liquid hydrogen was also used in the Tupolev Tu-155 experimental transport airplane in the end of the 1980s. In 2004, the final technical report of the EU project CRYOPLANE [43] concluded that "detailed analysis of 'conventional' engines has confirmed that a hydrogen-fuelled engine will be as efficient as a kerosene engine in terms of energy consumed." and that "hydrogen produced on the basis of renewable energy has been confirmed as offering a chance of continuing long-term growth of aviation without damaging the atmosphere". Recently, aircraft such as the HY4, developed at the German Aerospace Agency DLR, have demonstrated the use of hydrogen fuel-cells for flying. In terms of price, the hydrogen should be in the order of 2 to $3 € / \mathrm{kg}$ to compete with jet fuel. The market potential is very large, in the order of 100,000,000 tons of hydrogen if the aviation industry makes the transition. Note that, in contrast to the fuel market of cars, buses or trucks, hydrogen does not compete with batteries because of their much greater weight to energy ratio.

Other markets for hydrogen include industrial applications. In contrast to most mobility applications, these markets are well established and are characterized by large volumes. According to [44], "over 60 million tons of hydrogen are produced annually for industrial purposes, with roughly one half being used for producing ammonia". Ammonia is then used for production of fertilisers. Almost all of the industrial hydrogen $(95 \%)$ is produced from fossil fuels through the steam methane reforming process. It results in ammonia production being the major contributor to the greenhouse gas emissions associated with fertiliser production, accounting for over $1 \%$ of global emissions [45]. Other large industry uses of hydrogen include crude oil processing in refineries or methanol production in the chemical industry [40]. Hydrogen may also be used by steel manufacturers to produce low-carbon emission steel. These hydrogen uses are characterized by considerable quantities of hydrogen consumption. At the Wesseling refinery site in Germany, the refineries and plants on site use approximately 180,000 tons of hydrogen per year [46]. In these large industries, hydrogen is typically obtained at site at a typical cost in the range of 1.2 to $2 € / \mathrm{kg}$.

Light industry hydrogen uses include cooking oil and fat production, glass production, electronic industry and metallurgy. According to the data in [40], the light industry hydrogen market in the European Union is in the order of 80,000 tons per year. Still according to [40], it is challenging to define a generic light industry hydrogen price because it varies significantly depending on hydrogen 
production and distribution patterns, customer related factors (e.g agreement duration) and location related factors (e.g distance to hydrogen sources). Nevertheless, a target $\mathrm{H} 2$ selling price of $5 € / \mathrm{kg}$ was quoted in [40].

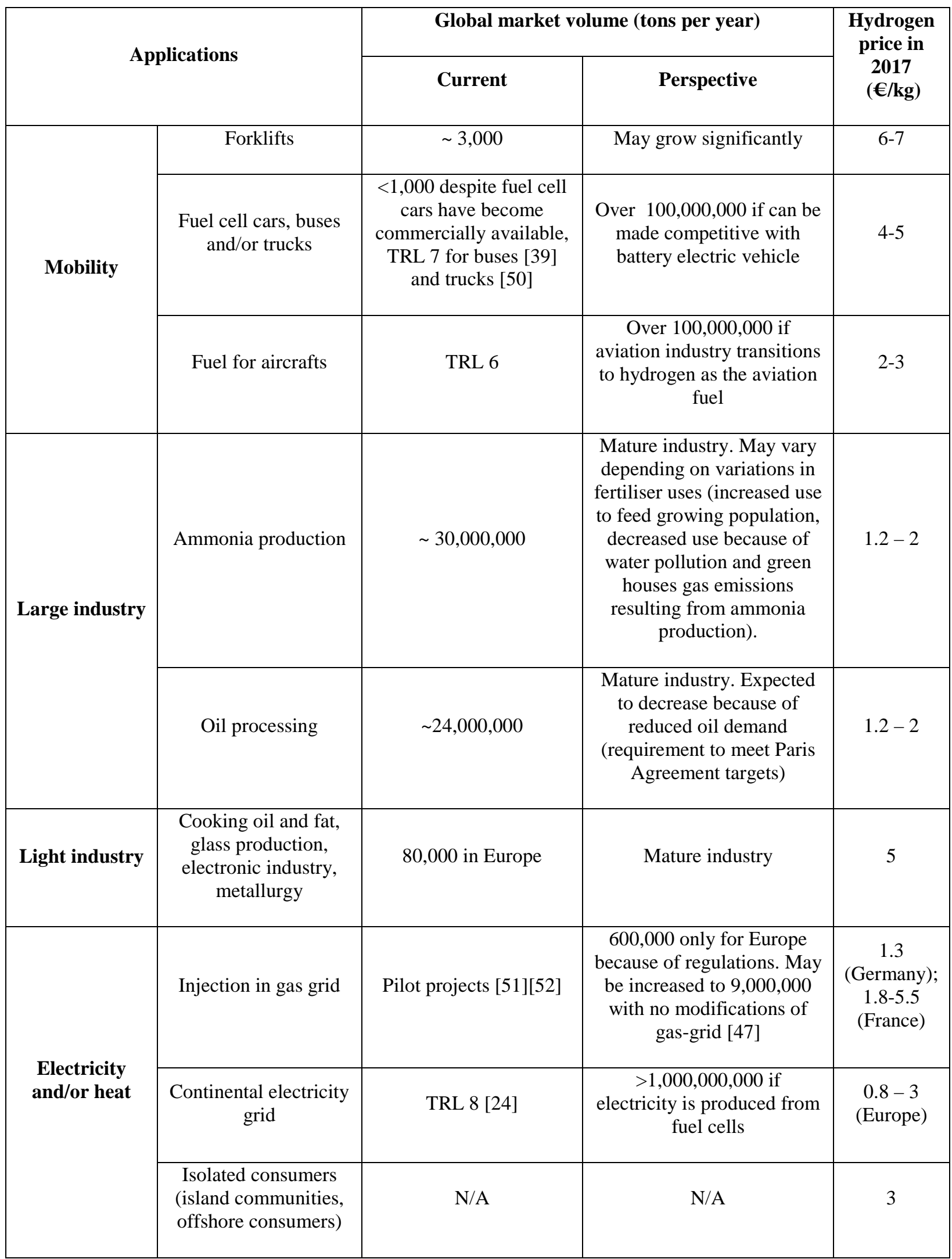

Table 2. Table of global market volume for hydrogen for various applications 
Direct injection of hydrogen gas into gas grids is another possible market for hydrogen. Although there are strong regulations on the share of hydrogen in the gas mix ( $2 \%$ in volume, $0.3 \%$ in mass), the market can still be very significant. Indeed, in Europe, the natural gas consumption was in the order of 200 million tons per year. If $0.3 \%$ were hydrogen, the market would be 600,000 tons per year. According to [47] (page 328), it was shown in the European project NATURALHY that it may be possible to add up to $4.5 \%$ mass hydrogen (30\% in volume) with no modifications to the existing gas grid. It would increase the market size 15 fold (9,000,000 tons). According to [40], the hydrogen price would be $1.3 € / \mathrm{kg}$ (Germany) to $1.8-5.5 € / \mathrm{kg}$ (France). The higher value in the range corresponds to bio-methane which benefits from a feed-in tariff.

Eventually, the hydrogen can be used to generate electricity. Electricity price excluding taxes is in the range $0.05-0.18 € / \mathrm{kWh}$ on the European continental grid market [48]. Efficiency of electricity generation with fuel cell is in the order of 50\% [24][37]. Neglecting the investment cost, the hydrogen price should be in the range $0.8-3 € / \mathrm{kg}$ for competitiveness with other electricity generation sources. Note that recent research has shown that energy efficiency up to $68 \%$ could be achieved for electricity generation with a hydrogen combustion power plant based on an adapted Graz cycle [49]. Moreover, in the case of co-generation of heat and electricity, the efficiency could increase to $85 \%$ which would make a higher price acceptable. Moreover, note that the electricity would be available on demand and the plant would be able to provide ancillary services to the grid (load balancing, frequency control) which may provide additional revenue sources to the plant, thus also making a higher price of hydrogen acceptable. For the isolated communities market (non-grid connected islands, offshore consumers), the generated electricity would compete with the one from diesel generators or other renewable energy sources, such as wind power and solar power combined with energy storage. According to [40], the variable cost for a diesel generator can be up to $200 € / \mathrm{MWh}$. Assuming a fuel cell efficiency of $50 \%$, the hydrogen price should be in the order of $3 € / \mathrm{kg}$ to be able to compete. It corresponds to the higher end of the price range for the European continental grid market. Again, in the case of co-generation of heat and electricity, the increase in efficiency could make a higher hydrogen price acceptable.

Table 2 summarizes the hydrogen markets that were discussed in this section. It appears that there are already existing markets for hydrogen that would be produced by far offshore wind energy converters provided that the cost of the hydrogen is competitive. Markets with the highest hydrogen price are fuel cell forklifts and light industry uses. For those markets the hydrogen price is in order of 5 to $7 € / \mathrm{kg}$. The market volume exceeds 100,000 tons per year globally. However, the price corresponds to the hydrogen delivered to the consumer. It includes the distribution costs which can be significant [40]. Issues and costs related to hydrogen transport and hydrogen distribution are discussed in the next section.

For existing markets, hydrogen for isolated consumers has the second highest hydrogen price. These consumers may be island communities or offshore consumers (oil \& gas platforms). They are expected to be closer to where hydrogen would be produced with far offshore wind energy converters than consumers using hydrogen for forklifts or light industry uses. Thus, the hydrogen transport and distribution costs would be significantly smaller which could result in a competitive hydrogen price. However, the market volume is unclear. It may be rather small. Eventually, the large industry uses will yield huge market volumes if the hydrogen price is reduced to a competitive level. .

To conclude, one can see that there are existing market opportunities for the hydrogen that would be produced by far offshore wind energy converters provided that the hydrogen price is in the order of $3-5 € / \mathrm{kg}$. If this target is met, the business volume of far offshore producing hydrogen companies may exceed 500 million euros. Then, costs may reduce thanks to the learning effect. If it could lead to halving the costs, far offshore produced hydrogen may become competitive with steam methane reforming for hydrogen supply for the large industry market. The business volume of far offshore producing hydrogen companies might then exceed several tens of billion euros. In the meantime, other mobility markets (cars, buses, trucks, airplanes) and electricity and heat markets may develop which may lead to a further increase in the market size by one or two orders of magnitude. 


\section{Scenarios for production, transportation and distribution of hydrogen produced by fleets of far offshore wind energy converters}

\subsection{Description of possible options}

The energy density of hydrogen gas under normal temperature and pressure conditions is 33 $\mathrm{kWh} / \mathrm{kg}$. It is greater than any other conventional fuel, as can be seen in Figure 4 . However, it can be seen that its volumetric density is also the smallest (only $2.9 \mathrm{kWh} . \mathrm{Nm}^{3}$ in standard temperature and pressure conditions). In contrast, diesel volumetric density is more than 3,000 times greater. The low volumetric density is a well-known challenge for hydrogen storage and transportation.

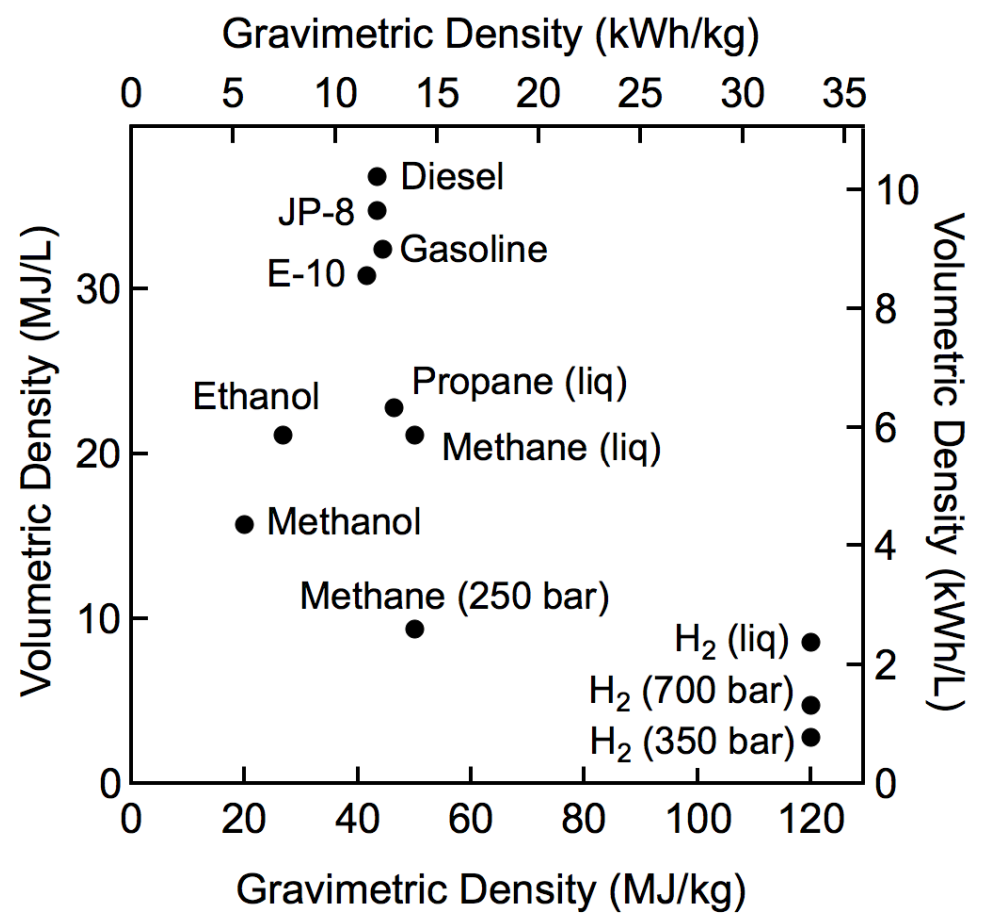

Figure $4 \quad$ Comparison of specific energy (energy per mass or gravimetric density) and energy density (energy per volume or volumetric density) for several fuels based on lower heating values. The picture is taken from [53]

To move large amounts of hydrogen gas, the only option is pipelines according to [54]. Unfortunately, it is not feasible for far offshore mobile wind energy converters. Therefore, other options must be found. Similar to natural gas, most developed solutions consist of moving tanks of liquefied gas or compressed gas.

Figure 5 and Figure 6 depict four different options for the production, transportation and distribution of hydrogen produced by fleets of far offshore wind energy converters. In option 1 and 3 , the transported hydrogen is liquid (LH2), whereas in options 2 and 4, it is compressed (CGH2).

In options 1 and 2, depicted in Figure 5, the central element is the hydrogen terminal. In this scenario, fleets of far offshore wind energy converters sail to the shore-based terminal to unload the hydrogen when their onboard storage tanks are full. Note that the terminal is located inside the large domain. The sailing speed of far offshore wind energy converters may be as high as 20 knots according to [14]-[17]. At such speed, it will take the converter only 27 hours to traverse a distance of $1000 \mathrm{~km}$ to reach the terminal. Therefore, the $1,000 \mathrm{~km}$ wide coastal band can be considered as the typical deployment area for options 1 and 2. Let us recall that a good deal of the global resource (circa $30 \%$ ) is available in these areas, as can be seen in Figure 3. 
Once the hydrogen is unloaded, it must be transported to the end-users. In the present study, it is assumed that the distance to the farthest end-user is $600 \mathrm{~km}$ from the terminal. The round-trip to deliver hydrogen to such end-users by truck would take 2 days assuming an average truck speed of 60 $\mathrm{km} / \mathrm{h}$. It is believed that delivery to end-users located at greater distances would be challenging from the cost perspective. Moreover, most of the global population and activity is located close to shore. Thus, it is believed that $600 \mathrm{~km}$ is an appropriate trade-off between market size and delivery costs.

For option 1, LH2 can be carried to end-users using trucks and LH2 semitrailers. Note that road transportation of cryogenic liquid hydrogen in semitrailer is a mature technology [47]. Typical capacity of a LH2 trailer is $3,500 \mathrm{~kg}$. Delivery cost is estimated to be $0.35 € / \mathrm{kg}$ for a $600 \mathrm{~km}$ roundtrip in [47]. For a $1,200 \mathrm{~km}$ round-trip, delivery cost may double, i.e. $0.70 € / \mathrm{kg}$.

For option 2, the compressed hydrogen gas can be delivered using tube trailers which are also a mature technology. However, the typical holding capacity of a tube trailer is much smaller than for LH2. According to [55] and [56], it is in the order of 300-340 kg of hydrogen gas for a storage pressure of 165 - 180 bars. Increasing the storage pressure can increase the capacity. Semitrailers of $1,100 \mathrm{~kg}$ have recently been built [56][57]. The storage pressure is 500-540 bars. Note that the trailer mass is $39,500 \mathrm{~kg}$ for a $1,155 \mathrm{~kg}$ capacity in [57], thus the ratio of stored hydrogen mass to trailer mass is only 0.03 . In comparison, the mass of a LH2 semitrailer is $25,500 \mathrm{~kg}$ for a $3,463 \mathrm{~kg}$ capacity according to [47], thus a ratio of $0.13,4.5$ times greater.

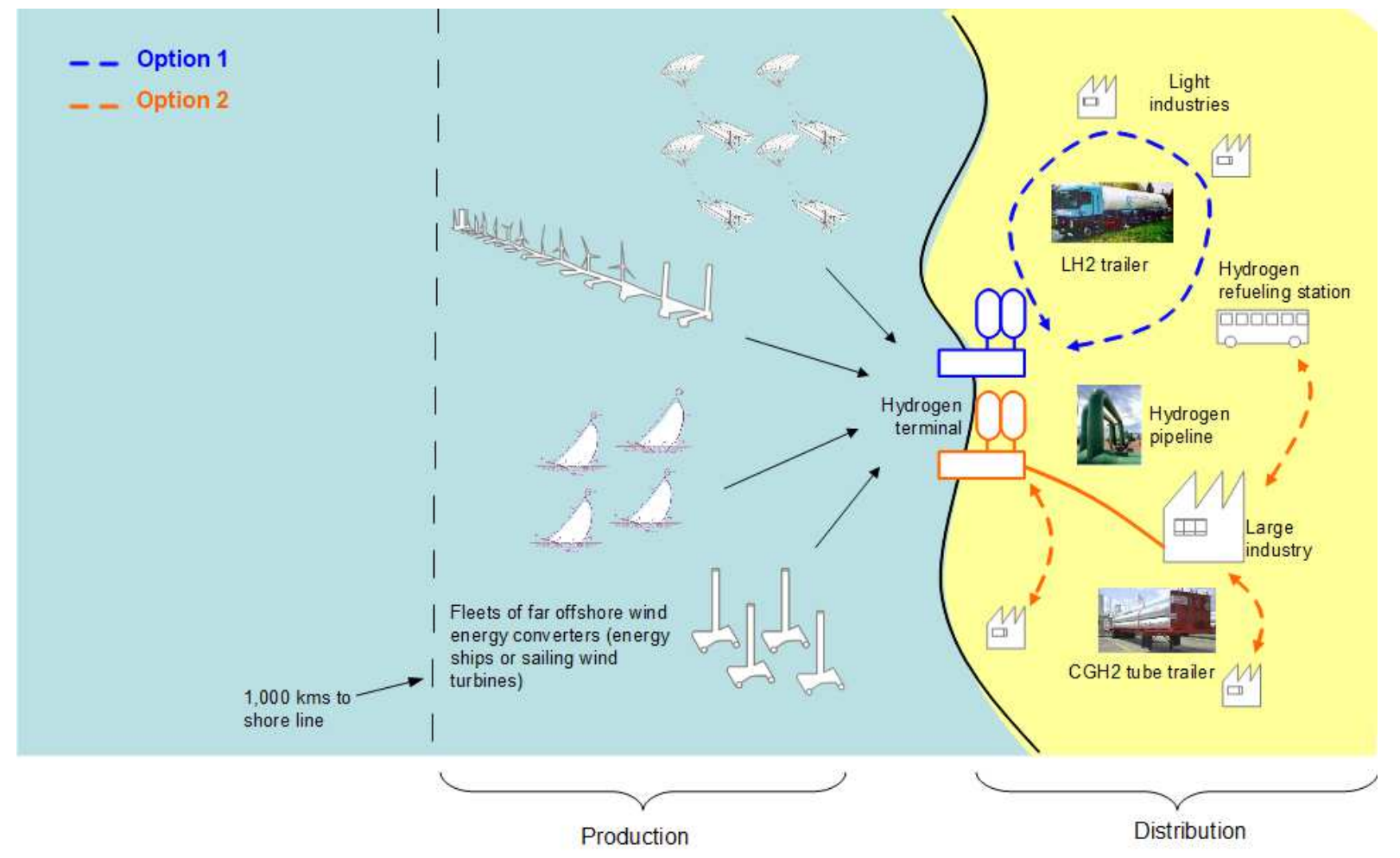

Figure $5 \quad$ Illustration of options 1 and 2 for distribution of hydrogen produced by fleets of far offshore wind energy converters. In option 1 (in blue), hydrogen is liquid (LH2) whereas in option 2 (in orange), it is compressed (CHG2). Converters are expected to harvest wind energy in a $1,000 \mathrm{~km}$ wide coastal band in these options. Picture of LH2 truck (C) Air Liquide.

The low capacity of CGH2 trailers is an issue for truck delivery with respect to costs. Indeed, as it is less than a third of the capacity of a LH2 semitrailer, it is expected that the delivery cost is more than three times that for $\mathrm{LH} 2$, i.e. $2.1 € / \mathrm{kg}$ for a $1,200 \mathrm{~km}$ round-trip. That is why it is assumed in option 2 that there is a $300 \mathrm{~km}$ long pipeline that carries the hydrogen inland, for example to a large industry (note that there are already $15,000 \mathrm{~km}$ of hydrogen pipelines all over the world [47]). It is further assumed that there is a filling station at the end of this pipeline where $\mathrm{CGH} 2$ trailers can be filled. Eventually, the remaining distance to reach the farthest end-user (600 km from terminal) is 300 $\mathrm{km}$ (round-trip $600 \mathrm{~km}$ ). The delivery cost by truck is then reduced to $1.1 € / \mathrm{kg}$. 
In options 3 and 4 depicted in Figure 6, the fleets of wind energy converters are deployed farther than 1,000 km offshore. This further offshore deployment may be necessary to access more areas (see section 2) and/or areas with low conflicting uses of the sea space. In these options, offshore terminals and hydrogen carriers are required to avoid long transit times between the production zone and the shore terminal which would be detrimental for the capacity factor of the wind energy converters. Offshore terminals are used for offloading the converters when they are full. The hydrogen carriers transport the energy from the offshore terminals to the onshore terminals. From the onshore terminals, the distribution is similar to options 1 and 2.

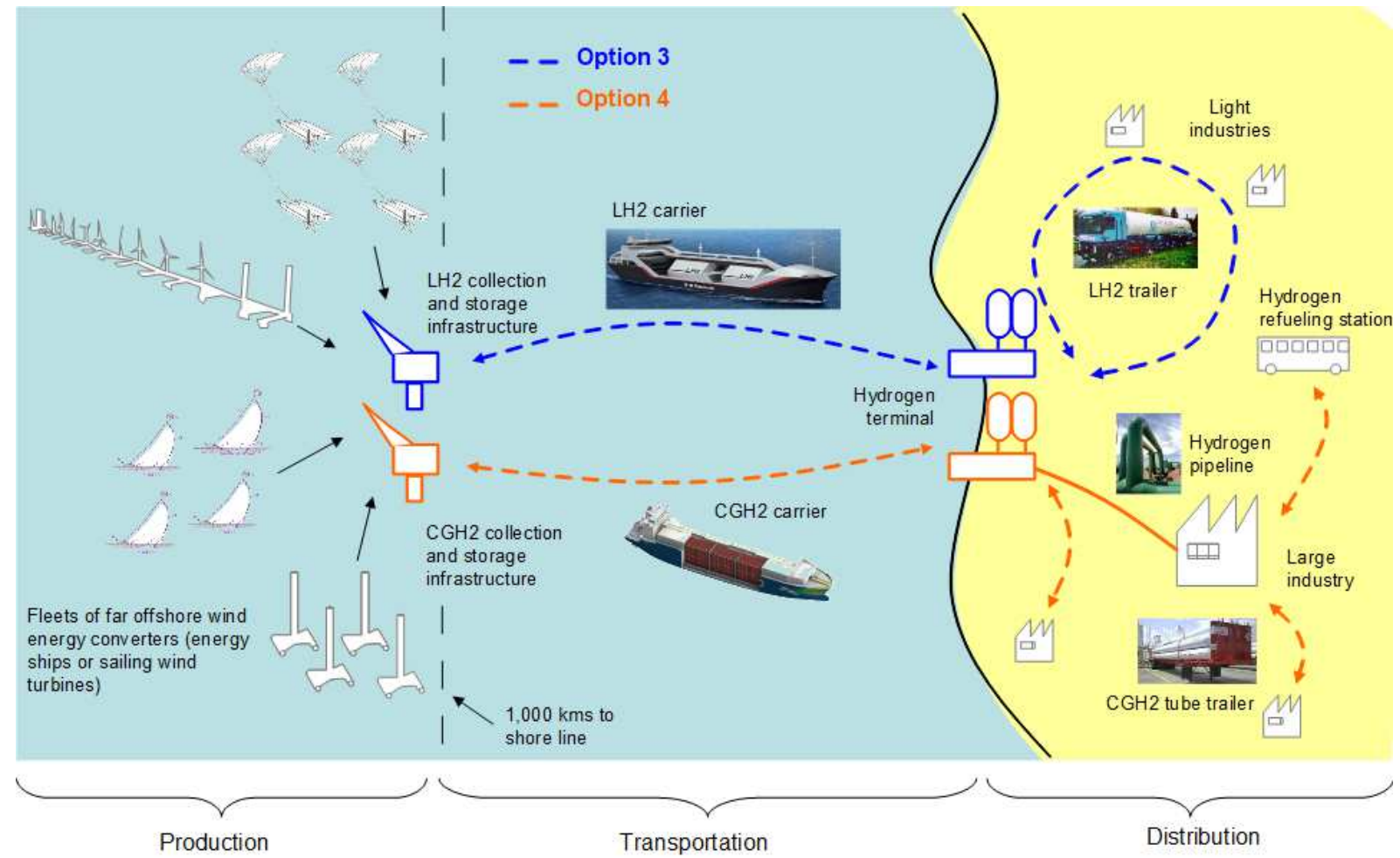

Figure $6 \quad$ Illustration of options 3 and 4 for transport and distribution of hydrogen by fleets of far offshore wind energy converters. In comparison to options 1 and 2, the converters sail further offshore which requires offshore collection infrastructures and dedicated carriers. Picture of the LH2 carrier (c) KHI. Picture of the CNG carrier (c) Fincantieri.

In option 3, the hydrogen is carried liquid. The carrier is a LH2 carrier. There have been proposals and engineering studies of cryogenic LH2 carriers [47][58]. Apart from being more challenging because of the lower boiling temperature, LH2 marine transportation bears many similarities with LNG marine transportation in LNG carriers, which is a mature and well-developed technology. A LH2 carrier fitted with 4 Horton spheres [55] of 3,500 $\mathrm{m}^{3}$ each would have a capacity of approximately 1,000 tons. Its length would be in the order of $100 \mathrm{~m}$ and its breadth in the order of $20 \mathrm{~m}$.

In option 4, the hydrogen is compressed. The world's first CNG (compressed natural gas) carrier - the Jayanti Baruna - was launched in 2016 [59]. Such ship design could be adapted to transport $\mathrm{CGH} 2$ with little modifications. Therefore, $\mathrm{CGH} 2$ carriers should be relatively easy to develop using current technology. However, the capacity would be small. Indeed, according to [60], the energy that can be transported by a $100 \mathrm{~m}$ long $18 \mathrm{~m}$ wide 7,000 tons displacement CNG carrier is approximately $6,750 \mathrm{MWh}$ at a storage pressure of 250 bars. The storage volume is $2,700 \mathrm{~m}^{3}$. Extrapolating to marine transportation of $\mathrm{CGH} 2$, the transported mass in the same volume is approximately 54 tons at 250 bars. It corresponds to 1,800 MWh of stored energy which is almost four times smaller than for CNG. With such small capacity, marine transportation of CGH2 is unlikely to be economic. In the long term, it may be possible to increase the storage pressure to 700 bars, which would allow transportation of 150 tons, corresponding to approximately 5,000 MWh. It is believed that this higher capacity, if achievable, could lead to better prospects. 
Overall, all four options seem technically feasible for hydrogen transportation and distribution. Consequently, all of them have been retained for further analysis with respect to energy efficiencies and costs, which is the topic of the following sections.

\begin{tabular}{|c|c|c|c|c|c|c|c|c|}
\hline \multirow[t]{2}{*}{ Vessel } & & \multirow[t]{2}{*}{ Unit } & \multicolumn{2}{|c|}{ Option 1} & \multicolumn{2}{|c|}{ Option 2} & \multirow{2}{*}{$\begin{array}{c}\text { Option } 3 \\
\begin{array}{c}\text { Longer } \\
\text { term }\end{array}\end{array}$} & \multirow{2}{*}{$\begin{array}{c}\text { Option } 4 \\
\begin{array}{c}\text { Longer } \\
\text { term }\end{array}\end{array}$} \\
\hline & & & $\begin{array}{l}\text { Short } \\
\text { term }\end{array}$ & $\begin{array}{l}\text { Longer } \\
\text { term }\end{array}$ & $\begin{array}{l}\text { Short } \\
\text { term }\end{array}$ & $\begin{array}{c}\text { Longer } \\
\text { term }\end{array}$ & & \\
\hline \multirow[t]{6}{*}{$\begin{array}{l}\text { Far offshore wind } \\
\text { converters }\end{array}$} & Rated capacity & $\mathrm{kW}$ & 1,000 & 2,000 & 1,000 & 2,000 & 2,000 & 2,000 \\
\hline & Capacity factor & - & $80 \%$ & $90 \%$ & $80 \%$ & $90 \%$ & $90 \%$ & $90 \%$ \\
\hline & Storage vector & - & LH2 & LH2 & CGH2 & $\mathrm{CGH} 2$ & LH2 & $\mathrm{CGH} 2$ \\
\hline & $\begin{array}{l}\text { Onboard storage } \\
\text { capacity at full } \\
\text { production }\end{array}$ & Weeks & 1 & 1 & 1 & 1 & 1 & 1 \\
\hline & $\begin{array}{l}\text { Number of } \\
\text { converters per fleet }\end{array}$ & - & 100 & 300 & 100 & 300 & 100 & 300 \\
\hline & $\begin{array}{l}\text { Maximum distance } \\
\text { to offloading } \\
\text { terminal in operation }\end{array}$ & $\mathrm{km}$ & 1,000 & 1,000 & 1,000 & 1,000 & 1,000 & 1,000 \\
\hline \multirow[t]{2}{*}{ Offshore terminal } & Rated capacity & tons/day & - & - & - & - & 215 & 247 \\
\hline & Storage capacity & days & - & - & - & - & 4 & 0.5 \\
\hline \multirow[t]{5}{*}{ Carrier } & Capacity & tons & - & - & - & - & 1,000 & 150 \\
\hline & Distance (one-way) & $\mathrm{km}$ & - & - & - & - & 1,000 & 1,000 \\
\hline & Service-speed & knts & - & - & - & - & 15 & 15 \\
\hline & $\begin{array}{l}\text { Round-trip duration } \\
\text { including loading } \\
\text { and unloading }\end{array}$ & days & - & - & - & - & 4 & 4 \\
\hline & $\begin{array}{l}\text { Number of carriers } \\
\text { per offshore } \\
\text { terminal }\end{array}$ & - & - & - & - & - & 1 & 7 \\
\hline \multirow[t]{2}{*}{ Onshore terminal } & Rated capacity & tons/day & 29 & 215 & 32 & 247 & 210 & 244 \\
\hline & Storage capacity & days & 1 & 1 & 1 & 1 & 4 & 1 \\
\hline \multirow[t]{2}{*}{ Pipeline } & Rated power & MW & - & - & 45 & 350 & - & 350 \\
\hline & Length & $\mathrm{km}$ & - & - & 300 & 300 & - & 300 \\
\hline \multirow[t]{4}{*}{ Truck } & Capacity & $\mathrm{kg}$ & 3,500 & 3,500 & 1,100 & 1,100 & 3,500 & 1,100 \\
\hline & $\begin{array}{l}\text { Maximum delivery } \\
\text { distance (one-way) }\end{array}$ & $\mathrm{km}$ & 600 & 600 & 300 & 300 & 600 & 300 \\
\hline & $\begin{array}{l}\text { Round-trip duration } \\
\text { including loading } \\
\text { and unloading }\end{array}$ & days & 2 & 2 & 1 & 1 & 2 & 1 \\
\hline & $\begin{array}{l}\text { Number of trucks } \\
\text { per terminal }\end{array}$ & - & 16 & 122 & 29 & 221 & 118 & 221 \\
\hline
\end{tabular}

Table 3. Parameters and modelling assumptions for comparison of options 1 to 4 for transportation and distribution of hydrogen produced by fleets of far offshore wind energy converters.

Parameters and modelling assumptions for the analysis are summarized in Table 3. Regarding options 1 and 2, one can see that a distinction has been made between what is thought to be achievable in the short term (say 2025-2030) and in a longer term (say 2035-2040). Indeed, for these options, it should be noted that all technologies involved in the hydrogen transportation and distribution are currently available, most of them on a commercial basis, apart of course from the wind energy converters. Thus, they could be implemented as soon as far offshore wind energy converters would 
become available. In the short term, it is believed that converters of $1 \mathrm{MW}$ rated capacity with $80 \%$ capacity factor can be achieved. In the longer term, it is assumed that a rated capacity of $2 \mathrm{MW}$ or greater, with $90 \%$ load factor can be achieved. Eventually, regarding options 3 and 4, they assume LH2 and CGH2 carriers that are not available today. Thus, these options should only be regarded as for the longer term.

\subsection{Techno-economic analysis of option 1}

Production cost of hydrogen through water electrolysis depends mainly on the electrolyzer capital cost and efficiency as well as the electricity cost and capacity factor of the plant [37][61][62].

According to [62] or [63], alkaline electrolysers currently cost $1,000 € / \mathrm{kW}$. In [64], the electrolyser system capital cost (including ancillaries) is currently $1,200 € / \mathrm{kW}$ for $1 \mathrm{MW}$ capacity. It is expected to decrease to $900 € / \mathrm{kW}$ by 2025 . The energy consumption is currently $58 \mathrm{kWh} / \mathrm{kg}$ and expected to decrease to $55 \mathrm{kWh} / \mathrm{kg}$ by 2025 . It is in agreement with the data in [63]. Thus, an efficiency of $55 \mathrm{kWh} / \mathrm{kg}$ and a system cost of $900 € / \mathrm{kW}$ are considered for the short term. For the longer term, it is assumed that the system cost could be further reduced to $600 € / \mathrm{kW}$ and the energy consumption could be reduced to $50 \mathrm{kWh} / \mathrm{kg}$. Note that these values correspond to the expected values for a 5 MW capacity plant for 2025 in [64].

For operation, the electrolyser needs to be fed with high purity fresh water. It is assumed that it is obtained through double desalination of sea water using a reverse osmosis desalination system. According to the data in [28], the energy consumption and capital cost is less than $1 \%$ of that for the electrolyser. Thus, it is neglected in the analysis.

Regarding the on-board electricity cost, it is certainly the most difficult to estimate as no energy ships or sailing wind turbines have been built yet. Nevertheless, a starting point may be the expected levelised cost of energy for commercial floating wind turbines. According to [5], it is 0.11 $€ / \mathrm{kWh}$. Mooring and anchors, installation and balance of plant account for a little more than $30 \%$ of the capital cost. Other costs such as operation and maintenance costs are usually accounted as a percentage of the capital cost. Thus, excluding costs related to station-keeping, the cost of energy for commercial floating wind turbines reduce to $0.08 € / \mathrm{kWh}$. Moreover, still in [5], it is reported that the capacity factor of offshore bottom-fixed wind turbines is typically $40 \%$. For floating wind, it could even be higher. Indeed, the measured capacity factor for the Hywind floating wind turbine prototype in Norway is approximately $50 \%$. Assuming a $90 \%$ capacity factor could be achieved, the cost of energy would reduce further down to $0.04 € / \mathrm{kWh}$.

A $0.05 € / \mathrm{kWh}$ cost of energy is the typical cost for newly built land-based wind farms in the U.S [65] despite a capacity factor of only 30\%. In [66], it is reported that a convoy of 10 energy ships with total power $20 \mathrm{MW}$ could cost $40 \mathrm{M} €$. Thus the capital cost per $\mathrm{kW}$ would be twice that of land based wind turbines (approximately $1,000 € / \mathrm{kW}$ ), but the capacity factor could be three times greater, resulting in a cost of energy estimate of $0.03 € / \mathrm{kWh}$.

In [28], an energy ship design is optimized with respect to cost. For the optimal configuration, the hydrogen cost is found to be $13.9 € / \mathrm{kg}$. It corresponds to an on-board electricity cost of 0.17 $€ / \mathrm{kWh}$. This estimate is likely conservative because it is based on published cost data for manned ships designed for very different purposes than wind energy conversion. Therefore, it can be expected that unmanned autonomously operating energy ships will have significantly smaller cost. Moreover, their estimate is for a ship that would be the first-of-a-kind. Experience from other renewable energy industries shows that cost can be reduced by an order of magnitude within a few decades as the industry develops and installed capacity increases. For onshore wind, the cost has been divided by 4 from the early 1980s. Assuming the same cost reduction can be achieved for energy ships, the long term cost estimate is $0.04 € / \mathrm{kWh}$ for the electricity on-board the ship.

Therefore, $0.04 € / \mathrm{kWh}$ has been retained in this study for the longer term cost of electricity available aboard far offshore wind energy converters. For the short term, it is likely that the industry will require a significantly greater cost to enable its development. Thus, twice the longer term cost target has been retained for the short term cost, i.e., $0.08 € / \mathrm{kWh}$. 
Finally, the hydrogen production $\operatorname{cost}{C_{H_{2}}}^{\text {electrolyzer }}$, in $€$ per kilogram, is estimated by:

$$
C_{H_{2}}^{\text {electrolyzer }}=\frac{\left(\varphi_{\text {installation }}+\varphi_{O \& M} n\right) C_{\text {electrolyzer }}}{8760 n \lambda \times \frac{\eta_{\text {electrolyzer }}}{33}}+\frac{33}{\eta_{\text {electrolyzer }}} C_{\text {electricity }}^{\text {aboard }}
$$

where $C_{\text {electrolyzer }}$ is the electrolyzer capital cost, $C_{\text {electricity }}^{\text {aboard }}$ is the aboard electricity cost, $\varphi_{\text {installation }}$ is the installation factor (taken equal to 1.2 following [55]), $n$ is the system lifetime (20 years), $\lambda$ is the capacity factor and $\varphi_{O \& M}$ is the operation and maintenance cost. Following [64], a $4 \%$ operation and maintenance cost is retained for the short term and $3 \%$ for the longer term.

The techno-economic parameters used in the calculation of the hydrogen production cost are summarized in Table 4. Using equation 2, the hydrogen cost is estimated to $5.11 € / \mathrm{kg}$ for the short term and $2.34 € / \mathrm{kg}$ for the longer term.

\begin{tabular}{|c|c|c|c|c|}
\hline Parameter & Unit & Symbol & Short term & Longer term \\
\hline Aboard electricity cost & $€ / \mathrm{kWh}$ & $C_{\text {electricity }}$ aboard & 0.08 & 0.04 \\
\hline Electrolyzer system cost & $€ / \mathrm{kW}$ & $C_{\text {electrolyzer }}$ & 900 & 600 \\
\hline Installation factor & - & $\varphi_{\text {installation }}$ & 1.2 & 20 \\
\hline Lifetime & Years & $n$ & 20 & $3 \%$ \\
\hline Operation \& maintenance cost & - & $\varphi_{\text {O\&M }}$ & $4 \%$ & $66 \%$ \\
\hline Electrolyzer efficiency & - & $\eta_{\text {electrolyzer }}$ & $60 \%$ & $90 \%$ \\
\hline Load factor & - & $\lambda$ & $80 \%$ & 2.34 \\
\hline Hydrogen cost at electrolyzer & $€ / \mathrm{kg}$ & $C_{H_{2}}$ & 5.11 & \\
\hline
\end{tabular}

Table 4. Techno - economic parameters for estimation of the hydrogen production cost by the electrolyzer

Energy requirements for liquefaction or compression of hydrogen gas are discussed in e.g. [47] and [54]. In theory, liquefaction of hydrogen requires $3.3-3.9 \mathrm{kWh} / \mathrm{kg}$. However, in practice energy requirements are typically $10-13 \mathrm{kWh} / \mathrm{kg}$ which corresponds to $30-36 \%$ of the fuel energy. Moreover, it should be noted that the energy for hydrogen liquefaction is electric energy [47]. That is why the hydrogen must be liquefied on board the offshore wind energy conversion systems, where electricity is directly available. In contrast, electricity must be produced from fuels on the offshore collection infrastructure. Obviously, the fuel of choice would be the hydrogen transiting through the platform. Electricity would be produced using fuel cells for which the efficiency is less than 50\% [47]. Thus, $60-72 \%$ of the hydrogen would be required for hydrogen liquefaction! For the sake of comparison, only 8 to $10 \%$ of the fuel is used for natural gas liquefaction [67]. Note that the energy requirement for hydrogen liquefaction may reduce to $7 \mathrm{kWh} / \mathrm{kg}$ with novel liquefaction technologies (21\% of fuel energy) [54]. According to [68], the energy cost may even reduce to $5 \mathrm{kWh} / \mathrm{kg}$ by using pressurized feed-in hydrogen gas at 60 bars instead of gas at ambient pressure. Eventually, electricity consumption of $11 \mathrm{kWh} / \mathrm{kg}$ is retained for the shorter term (25\% Carnot efficiency) and $9.6 \mathrm{kWh} / \mathrm{kg}$ for the longer term (29\% Carnot efficiency). 
Regarding costs of hydrogen liquefaction, comprehensive economic data can be found in [47]. With current technology, the liquefaction cost ranges from $1.51 € / \mathrm{kg}$ to $0.55 € / \mathrm{kg}$ for liquefaction plants of 7 to 72 tons of LH2/day, excluding electricity cost. Offshore wind energy converters with at least 50 to $100 \mathrm{MW}$ averaged power output are required to produce these large amounts of hydrogen. It can be expected that the costs of liquefaction plants on-board offshore wind energy converters would be higher. However, note that there are only ten commercial-scale liquefaction plants worldwide according to [47]. Thus, significant cost reductions may be achieved with increasing number of plants. Therefore, for the short term a cost of $0.81 € / \mathrm{kg}$ is assumed corresponding to the current cost for a 36 tons of LH2/day plant. For the longer term, a cost of $0.55 € / \mathrm{kg}$ is assumed, corresponding to the current cost for a 72 tons per day plant. Note that total liquefaction costs must include electricity costs.

Regarding on-board storage costs, $0.25 \% /$ day for boil-off and $70 € / \mathrm{kg}$ uninstalled cost are assumed according to [55] for small storage capacity. It is further assumed that the boil-off gas is recovered and re-liquefied. Following [55], an installation factor of 1.3, an indirect cost factor of 1.27 and $1 \%$ O\&M per year are taken into account leading to $0.23 € / \mathrm{kg}$ for the short term. In the longer term, a cost reduction of $20 \%$ is assumed.

At the terminal, offloading operations may lead to losses as large as 6\% according to [55]. Here, it is assumed that most of these losses are recovered and that the hydrogen is liquefied again. Moreover, it is assumed that the hydrogen terminal cost is similar to that of a LNG terminal, which is in the order of $0.11 € / \mathrm{kg}$ according to [67]. For the LH2 storage at the terminal, Horton spheres may be used. Their cost is approximately $60 € / \mathrm{kg}$ for $500 \mathrm{~m}^{3}$ and $25 € / \mathrm{kg}$ for $3,500 \mathrm{~m}^{3}$ [55]. Typical boil-off loss is $0.25 \% /$ day.

For hydrogen truck delivery, the cost has already been discussed in section 5.1. Regarding energy losses, they can be estimated to $0.5 \%$ losses during loading, $0.25 \% /$ day for boil-off during transport and 6\% during unloading according to [55]. For the longer term, it is assumed that unloading losses can be reduced to $5 \%$. Eventually, considering a 351 per $100 \mathrm{~km}$ fuel consumption for the truck, the energy consumption during delivery can be estimated to be $1 \mathrm{kWh} / \mathrm{kg}$.

Table 5 shows a summary of the techno-economic data for option 1 . It appears that in the short term, the energy cost of the delivered hydrogen would be in the range [68 - 74] $\mathrm{kWh} / \mathrm{kg}$ depending on the distance between the terminal and the customer. The corresponding energy efficiency range is [ 44 - 48\%]. The total cost would be high, ranging from 7.4 to $8.7 € / \mathrm{kg}$ of delivered hydrogen. The transportation and distribution costs including liquefaction and storage would represent a significant share. It would account for 2.3 to $3.6 € / \mathrm{kg}$, i.e. $31 \%$ to $41 \%$ of the total cost.

In the longer term, the energy cost could reduce to the range of [61 - 66] $\mathrm{kWh} / \mathrm{kg}$ depending on the delivery distance. The total cost could be in the range of $[3.6-4.4] € / \mathrm{kg}$. Thus, the delivered hydrogen could be competitive on several of the markets that are listed in Table 2 . The transportation and distribution costs would account for 1.3 to $2.1 € / \mathrm{kg}$. It is $36 \%$ to $47 \%$ of the total cost, thus the share of the transportation and distribution would increase by $5 \%$ in the longer term. 


\begin{tabular}{|c|c|c|c|c|c|c|c|c|c|c|c|c|c|}
\hline \multirow[t]{2}{*}{ Vessel } & \multirow[t]{2}{*}{ Process stage } & \multicolumn{3}{|c|}{ Energy production } & \multicolumn{3}{|c|}{ Energy consumption } & \multicolumn{2}{|c|}{ Hydrogen losses } & \multicolumn{3}{|l|}{ Cost } & \multirow[t]{2}{*}{ Comments } \\
\hline & & $\begin{array}{l}\text { Short } \\
\text { term }\end{array}$ & $\begin{array}{l}\text { Longer } \\
\text { term }\end{array}$ & Unit & $\begin{array}{l}\begin{array}{l}\text { Short } \\
\text { term }\end{array} \\
\end{array}$ & $\begin{array}{c}\text { Longer } \\
\text { term }\end{array}$ & Unit & $\begin{array}{l}\text { Short } \\
\text { term }\end{array}$ & $\begin{array}{c}\text { Longer } \\
\text { term }\end{array}$ & $\begin{array}{l}\text { Short } \\
\text { term }\end{array}$ & $\begin{array}{l}\text { Longer } \\
\text { term }\end{array}$ & Unit & \\
\hline \multirow[t]{4}{*}{$\begin{array}{l}\text { Offshore wind } \\
\text { energy } \\
\text { converter }\end{array}$} & $\begin{array}{l}\text { Average electricity } \\
\text { production }\end{array}$ & 800 & 1800 & $\mathrm{~kW}$ & - & - & - & - & - & 0.08 & 0.04 & $€ / \mathrm{kWh}$ & $\begin{array}{l}\text { Assumes } 1 \mathrm{MW} \text { power capacity and } 80 \% \\
\text { capacity factor for the short term and } 2 \mathrm{MW} \\
\text { capacity and } 90 \% \text { capacity factor for the } \\
\text { longer term. } \\
\text { For justification of cost assumptions, see text. }\end{array}$ \\
\hline & Electrolysis & 2,036 & 5,040 & $\mathrm{~kg} /$ week & 55.0 & 50.0 & $\mathrm{kWh} / \mathrm{kg}$ & - & - & 5.11 & 2.34 & $€ / \mathrm{kg}$ & $\begin{array}{l}\text { Assumes alkaline electroyzer with } 60 \% \\
\text { efficiency-900€/kW cost for the short term and } \\
66 \% \text { efficiency - } 600 € / \mathrm{kW} \text { cost for the longer } \\
\text { term [64]. }\end{array}$ \\
\hline & Liquefaction & 2,036 & 5,040 & $\mathrm{~kg} /$ week & 11.0 & 9.6 & $\mathrm{kWh} / \mathrm{kg}$ & - & - & 1.90 & 0.99 & $€ / \mathrm{kg}$ & $\begin{array}{l}\text { According to [47]. Assumes capital cost of } \\
1,500 € / \mathrm{kW} \text { and } 25 \% \text { Carnot efficiency for the } \\
\text { short term }(1,000 € / \mathrm{kW} \text { and } 29 \%) \text { for the } \\
\text { longer term. }\end{array}$ \\
\hline & Tank storage & 2,036 & 5,040 & kg/week & 0.2 & 0.2 & $\mathrm{kWh} / \mathrm{kg}$ & - & - & 0.15 & 0.10 & $€ / \mathrm{kg}$ & $\begin{array}{l}0,25 \% / \text { day for boil-off over } 1 \text { week. Boil-off } \\
\text { gas is recovered and re-liquefied.[55]. } \\
\text { Assumes } 70 € / \text { kg uninstalled storage cost [55] } \\
\text { and } 20 \% \text { reduction in long term. }\end{array}$ \\
\hline Subtotal & & 2,036 & $\begin{array}{l}5,040 \\
\end{array}$ & kg/week & 66 & 60 & kWh/kg & & & 7.2 & 3.4 & $f / \mathbf{k g}$ & \\
\hline \multirow[t]{2}{*}{ Terminal } & $\begin{array}{l}\text { Infrastructure } \\
\text { including offloading }\end{array}$ & 28.7 & 214 & tons/day & 0,6 & 0,5 & $\mathrm{kWh} / \mathrm{kg}$ & $1 \%$ & $1 \%$ & 0.11 & 0.11 & $€ / \mathrm{kg}$ & $\begin{array}{l}6 \% \text { losses during offloading operation } \\
\text { according to[55]. Assumes most of it is } \\
\text { recovered and re-liquefied. } \\
\text { Assumes costs similar to LNG terminal } \\
(1 \$ / \text { MMBtu, [67]) }\end{array}$ \\
\hline & Tank storage & 28.6 & 213 & tons/day & - & - & - & $0.25 \%$ & $0.25 \%$ & 0.01 & 0.01 & $€ / \mathrm{kg}$ & $\begin{array}{l}0.25 \% / \text { day for boil-off. } 60 € / \mathrm{kg} \text { uninstalled cost } \\
\text { for Horton spheres for } 500 \mathrm{~m} 3 \text { ( } 35 \text { tons) } \\
\text { capacity; } 25 € / \mathrm{kg} \text { for } 3,500 \mathrm{~m} 3 \text { ( } 245 \text { tons) } \\
\text { capacity. [55] }\end{array}$ \\
\hline Subtotal & & 28.6 & 213 & tons/day & 68 & 61 & $\mathrm{kWh} / \mathrm{kg}$ & $1,25 \%$ & $1,25 \%$ & 7.4 & 3.6 & $€ / \mathbf{k g}$ & \\
\hline \multirow[t]{3}{*}{ Truck } & Loading & 3,500 & 3,500 & $\mathrm{~kg} / 2$ days & - & - & - & $0.5 \%$ & $0.5 \%$ & - & - & - & $0.5 \%$ loss according to [55] \\
\hline & $\begin{array}{l}\text { Delivery including } \\
\text { unloading }\end{array}$ & 3,482 & 3,482 & $\mathrm{~kg} / 2$ days & 1 & 1 & $\mathrm{kWh} / \mathrm{kg}$ & $0.5 \%$ & $0.5 \%$ & 0.70 & 0.56 & $€ / \mathrm{kg}$ & $\begin{array}{l}0.25 \% / \text { day for boil-off according to[55]. Cost } \\
\text { estimates according to [47] and assuming } 20 \% \\
\text { longer term cost reduction }\end{array}$ \\
\hline & Unloading & 3,274 & 3,307 & $\mathrm{~kg} / 2$ days & - & - & - & $6 \%$ & $5 \%$ & - & - & - & $\begin{array}{l}6 \% \text { losses during unloading operation } \\
\text { according to[55]. Assumes reduction to } 5 \% \text { in } \\
\text { the longer term. }\end{array}$ \\
\hline Total & & 26.6 & 200 & tons/day & 74 & 66 & kWh/kg & $8 \%$ & $7 \%$ & 8.7 & 4.4 & $€ / \mathbf{k g}$ & \\
\hline
\end{tabular}

Table 5. Techno - economic data for option 1 for the production and distribution of hydrogen produced by far offshore wind energy converters. 


\subsection{Techno-economic analysis of option 2}

In option 2, the hydrogen production techno-economic data is the same as for option $1(0.08 € / \mathrm{kWh}$ electricity cost and $5.11 €$ per $\mathrm{kg}$ of hydrogen in the short term, $0.04 € / \mathrm{kWh}$ electricity cost and $2.34 € / \mathrm{kg}$ in the longer term). In preparation for storage aboard the wind energy converters, the produced hydrogen is compressed. The theoretical energy requirement to compress hydrogen from ambient pressure to 350 bars (respectively 700 bars) is $1.05 \mathrm{kWh} / \mathrm{kg}$ (respectively $1.36 \mathrm{kWh} / \mathrm{kg}$ ). In practice, energy costs of $1.7-6.4$ $\mathrm{kWh} / \mathrm{kg}$ have been measured with an average of $3.1 \mathrm{kWh} / \mathrm{kg}$ [54]. It is 3 to 4 times smaller than the energy requirement for hydrogen liquefaction. Regarding costs, uninstalled capital costs of a 1MW compressor (30 $\mathrm{kg} / \mathrm{h}$ ) is in the order of $145 \mathrm{k€}$ [55]. For a $2 \mathrm{MW}$ compressor, the uninstalled cost is in the order of $275 \mathrm{k} €$. Following [55], an installation factor of 2.0 and $4 \%$ O\&M per year are taken into account leading to $0.39 € / \mathrm{kg}$ for the $1 \mathrm{MW}$ compressor. For the $2 \mathrm{MW}$ compressor, the cost estimate is $0.18 € / \mathrm{kg}$. These costs take into account energy consumption $(3.1 \mathrm{kWh} / \mathrm{kg}$ for the short term and $2.0 \mathrm{kWh} / \mathrm{kg}$ for the longer term [54]). Following [55], a $0.5 \%$ loss is also taken into account.

Regarding storage, the uninstalled cost is in the order of $450 € / \mathrm{kg}$ according to [69]. Following [55], an installation factor of 1.3 and $1 \%$ O\&M per year are taken into account leading to $0.84 € / \mathrm{kg}$ for the short term for a storage capacity corresponding to one week of production at $1 \mathrm{MW}$. For the longer term, a $20 \%$ cost reduction is assumed.

The terminal cost is assumed to be similar to that of option 1. Losses are much smaller, in the order of $0.5 \%$ according to [55]. For storage, the same techno-economic data as for storage aboard the wind energy converters is used. It leads to $0.12 € / \mathrm{kg}$ in the short term for a one-day storage capacity. For the longer term, a $20 \%$ cost reduction is assumed.

According to [47], the energy consumption of a $100 \mathrm{MW} 300 \mathrm{~km}$ long pipeline is $0.2 \mathrm{kWh} / \mathrm{kg}$. The cost is $0.83 € / \mathrm{kg}$. Costs and energy consumption per km are assumed to be similar for a $45 \mathrm{MW}$ pipeline of the same length. Still according to [47], the energy consumption and cost for a $600 \mathrm{MW} 300 \mathrm{~km}$ long pipeline are 0.9 $\mathrm{kWh} / \mathrm{kg}$ and $0.19 € / \mathrm{kg}$. The same techno-economic data is used for the longer term $350 \mathrm{MW} 300 \mathrm{~km}$ long pipeline. In addition, a $0.5 \%$ energy loss is taken into account following [55].

For final delivery of the hydrogen by truck, the hydrogen needs first to be re-compressed to $500-540$ bars to be able to deliver $1,100 \mathrm{~kg}$ of hydrogen per trip [57]. The average energy consumption is $3.7 \mathrm{kWh} / \mathrm{kg}$ [54]. It could reduce to $2.4 \mathrm{kWh} / \mathrm{kg}$. According to [69], the compressor uninstalled cost is $7 \mathrm{M€}$ for compression of 1.67 tons/h. Following [55], an installation factor of 2.0 and $4 \%$ O\&M per year are taken into account leading to a cost of $0.24 € / \mathrm{kg}$ including energy costs $(0.05 € / \mathrm{kWh})$. For the longer term, a cost reduction of $20 \%$ is assumed for the compressor uninstalled cost. The effect is found to be marginal because energy costs are dominating. An energy loss of $0.5 \%$ is also taken into account [55].

For hydrogen truck delivery, the cost has already been discussed in section 5.1. For the longer term, a $20 \%$ cost reduction is assumed. Regarding energy losses, they can be estimated as $0.5 \%$ losses during loading and $0.5 \%$ during unloading according to [55]. Eventually, considering a 351 per $100 \mathrm{~km}$ fuel consumption for the truck, the energy consumption during delivery can be estimated to be $1.9 \mathrm{kWh} / \mathrm{kg}$.

Table 6 shows a summary of the techno-economic data for option 2. It appears that in the short term, the energy cost of the delivered hydrogen would be in the range [59 - 65] $\mathrm{kWh} / \mathrm{kg}$ depending on the distance between the terminal and the customer. The corresponding energy efficiency range is [51-56\%]. The total cost range would be 6.6 to $8.8 € / \mathrm{kg}$ of delivered hydrogen depending on the distance to the terminal and pipeline. The transportation and distribution costs including compression and storage would represent a significant share. It would account for 1.5 to $3.7 € / \mathrm{kg}$, i.e. $23 \%$ to $42 \%$ of the total cost.

In the longer term, the energy cost could reduce to the range [53 - 59] $\mathrm{kWh} / \mathrm{kg}$ depending on the delivery distance. The total cost could be in the range [3.3-4.7] $€ / \mathrm{kg}$. The transportation and distribution costs would account for 1.0 to $2.4 € / \mathrm{kg}$. It is $30 \%$ to $51 \%$ of the total cost. 


\begin{tabular}{|c|c|c|c|c|c|c|c|c|c|c|c|c|c|}
\hline \multirow[t]{2}{*}{ Vessel } & \multirow[t]{2}{*}{ Process stage } & \multicolumn{3}{|c|}{ Energy production } & \multicolumn{3}{|c|}{ Energy consumption } & \multicolumn{2}{|c|}{ Hydrogen losses } & \multicolumn{3}{|l|}{ Cost } & \multirow[t]{2}{*}{ Comments } \\
\hline & & $\begin{array}{l}\text { Short } \\
\text { term }\end{array}$ & $\begin{array}{c}\text { Longer } \\
\text { term }\end{array}$ & Unit & $\begin{array}{l}\text { Short } \\
\text { term }\end{array}$ & $\begin{array}{c}\text { Longer } \\
\text { term }\end{array}$ & Unit & $\begin{array}{c}\text { Short } \\
\text { term }\end{array}$ & $\begin{array}{c}\text { Longer } \\
\text { term }\end{array}$ & $\begin{array}{l}\text { Short } \\
\text { term }\end{array}$ & $\begin{array}{l}\text { Longer } \\
\text { term }\end{array}$ & Unit & \\
\hline \multirow[t]{4}{*}{$\begin{array}{l}\text { Offshore wind } \\
\text { energy } \\
\text { converter }\end{array}$} & $\begin{array}{l}\text { Average electricity } \\
\text { production }\end{array}$ & 800 & 1800 & $\mathrm{~kW}$ & - & - & - & - & - & 0.08 & 0.04 & $€ / \mathrm{kWh}$ & Same as for Table 5 \\
\hline & Electrolysis & 2,278 & 5,815 & $\mathrm{~kg} /$ week & 55.0 & 50.0 & $\mathrm{kWh} / \mathrm{kg}$ & - & - & 5.11 & 2.34 & $€ / \mathrm{kg}$ & Same as for Table 5 \\
\hline & $\begin{array}{l}\text { Compression to } 350 \\
\text { bars }\end{array}$ & 2,266 & 5,815 & kg/week & 3.1 & 2.0 & $\mathrm{kWh} / \mathrm{kg}$ & $0.5 \%$ & $0.5 \%$ & 0.39 & 0.18 & $€ / \mathrm{kg}$ & $\begin{array}{l}\text { Energy consumption according to [54]. Losses } \\
\text { and cost estimates according to [55]. }\end{array}$ \\
\hline & Tank storage & 2,266 & 5,815 & kg/week & - & - & - & - & - & 0.84 & 0.60 & $€ / \mathrm{kg}$ & $\begin{array}{l}\text { Assumes } 450 € / \mathrm{kg} \text { uninstalled storage cost [69] } \\
\text { and } 20 \% \text { longer term cost reduction }\end{array}$ \\
\hline Subtotal & & 2,266 & 5,815 & kg/week & 58 & 52 & kWh/kg & $0.5 \%$ & $0.5 \%$ & 6.4 & 3.1 & f/kg & Same as for Table 5 \\
\hline \multirow[t]{2}{*}{ Terminal } & $\begin{array}{l}\text { Infrastructure } \\
\text { including offloading }\end{array}$ & 32.2 & 248 & tons/day & - & - & - & $0.5 \%$ & $0.5 \%$ & 0.11 & 0.11 & $€ / \mathrm{kg}$ & $\begin{array}{l}0.5 \% \text { losses during offloading operation } \\
\text { according to[55]. For cost estimates, see Table } \\
5\end{array}$ \\
\hline & Tank storage & 32.2 & 248 & tons/day & - & - & - & - & - & 0.10 & 0.08 & $€ / \mathrm{kg}$ & $\begin{array}{l}\text { Assumes } 450 € / \mathrm{kg} \text { uninstalled storage cost [55] } \\
\text { and } 20 \% \text { longer term cost reduction. }\end{array}$ \\
\hline Subtotal & & 32.2 & 248 & tons/day & 59 & 53 & kWh/kg & $1.0 \%$ & $1.0 \%$ & 6.6 & 3.3 & $€ / \mathrm{kg}$ & \\
\hline Pipeline & & 32.0 & 247 & tons/day & 0.2 & 1.0 & $\mathrm{kWh} / \mathrm{kg}$ & $0.5 \%$ & $0.5 \%$ & 0.84 & 0.24 & $€ / \mathrm{kg}$ & $\begin{array}{l}\text { Assumes } 45 \mathrm{MW} \text { capacity } 300 \mathrm{~km} \text { long } \\
\text { pipeline for the short term and } 350 \mathrm{MW} \text { for the } \\
\text { longer term. Energy consumption and cost } \\
\text { estimates according to [47] Losses according } \\
\text { to [55]. }\end{array}$ \\
\hline Subtotal & & 32.0 & 247 & tons/day & 59 & 54 & kWh/kg & $1.5 \%$ & $1.5 \%$ & 7.5 & 3.6 & $€ / \mathbf{k g}$ & \\
\hline \multirow[t]{2}{*}{ Truck } & $\begin{array}{l}\text { Loading including } \\
\text { high pressure } \\
\text { compression }\end{array}$ & 1,100 & 1,100 & $\mathrm{~kg} /$ day & 3.7 & 2.4 & $\mathrm{kWh} / \mathrm{kg}$ & $1.0 \%$ & $1.0 \%$ & 0.24 & 0.23 & $€ / \mathrm{kg}$ & $\begin{array}{l}\text { Energy consumption according to [54]. Losses } \\
\text { and costs estimates according to[69]. }\end{array}$ \\
\hline & $\begin{array}{l}\text { Delivery including } \\
\text { unloading }\end{array}$ & 1,095 & 1,095 & $\mathrm{~kg} /$ day & 1.9 & 1.9 & $\mathrm{kWh} / \mathrm{kg}$ & $0.5 \%$ & $0.5 \%$ & 1.05 & 0.84 & $€ / \mathrm{kg}$ & $\begin{array}{l}0.5 \% \text { losses during offloading operation } \\
\text { according to[55]. Energy consumption } \\
\text { according to [47]. Cost estimates extrapolated } \\
\text { from Table } 5 \text { assuming one delivery per day } \\
\text { and a trailer capacity of } 1,100 \mathrm{~kg} \text { of CGH2 } 2 \\
\text { [69]. Assumes } 20 \% \text { longer term cost reduction. }\end{array}$ \\
\hline Total & & 31.5 & 243 & tons/day & 65 & 59 & kWh/kg & $3.0 \%$ & $3.0 \%$ & 8.8 & 4.7 & $€ / \mathbf{k g}$ & \\
\hline
\end{tabular}

Table 6. Techno - economic data for option 2 for the production and distribution of hydrogen produced by far offshore wind energy converters. 


\subsection{Techno-economic analysis of option 3}

For option 3, only the longer term is considered. The same techno-economic data as for option 1 is assumed for the wind energy converters, for truck delivery and for the on-shore terminal, but 4 days of storage are assumed. For the data of the offshore terminal, it is simply assumed that it is the same as for the on-shore terminal. Therefore, the only missing techno-economic data is for the LH2 carrier.

As for LNG carriers, some of the transported energy in LH2 carriers would be lost because of non-ideal insulation and gas boiling. Boil-off gas is frequently used in LNG carriers to power the ships. According to [67], 0.1 to $0.25 \%$ of the cargo is consumed per day of travel in LNG carriers. In [58], a similar boil-off rate $(0.2 \% /$ day $)$ has been estimated for a LH2 carrier. Assuming the ship speed to be 14 knots $(\sim 26 \mathrm{~km} / \mathrm{h})$ and recalling that assuming a distance of $1,000 \mathrm{~km}$ between the offshore terminal and the on-shore, the travel time for the liquid hydrogen tanker is 1.6 days. Thus, the energy losses during the travel are in the order of $0.3 \%$. Taking into account the return trip, the figure must be doubled, i.e. $0.6 \%$. It can be noted that it is much smaller than the losses due to hydrogen gas liquefaction.

Recalling that it has been assumed that the cargo is 1,000 tons of LH2, recovering the hydrogen boil-off losses for powering the ship corresponds to a total amount of $198 \mathrm{MWh}$. It corresponds to an average power of 2 MW over 4 days ( 3 days of travel plus one day for loading and unloading). In comparison, the propulsion power for ships of 7,000 - 10,000 tons capacity is typically $3-4 \mathrm{MW}$ [71]. Thus, it appears that it is a reasonable assumption to consider that the boil-off gas is used for powering the ship. Note that the gravimetric energy density of LH2 being twice that of LNG, it is likely that a LH2 tanker would be significantly lighter than a LNG tanker. It could result in an increased service speed which could reduce the travel energy losses and the ship operation cost.

Additional hydrogen losses occur during LH2 loading and unloading operations. For loading, $0.5 \%$ loss is assumed following [55]. For unloading, it is as high as 6\% for trucks according to the same reference. Quoting [55], "this loss occurs because of the difficulty in maintaining a low enough temperature in the transfer system". Therefore, it can be expected that this loss would be much smaller for the 1,000 tons cargo of the LH2 carrier. A $1 \%$ loss has been assumed.

Clearly, estimating the cost of marine transportation of LH2 is challenging because no LH2 carriers have yet been built. In [47], it is reported that the estimated construction cost for a LH2 carrier of 8,150 tons capacity designed in Germany in the late 1980s was $440 \mathrm{M} €$. In comparison, the LNG carrier construction cost is typically $200 \mathrm{M€}$ with a typical capacity in the order of $100,000 \mathrm{~m}^{3}$. In terms of energy, such a volume of LNG is equivalent to approximately 18,000 tons of hydrogen. Thus, it appears that the construction cost per $\mathrm{kg}$ of transported energy of a LH2 carrier may be 5 times that of a LNG carrier. Therefore, it can be expected that the charter rate of a LH2 carrier could be up to 5 times greater than that of a LNG carrier. However, according to [70], the charter rate accounts for only $45 \%$ of the marine transportation costs in the LNG supply chain. Energy consumption is the second most significant source of energy costs, accounting for $40 \%$ of the transportation costs. LH2 carriers may be significantly lighter than LNG carriers for the same amount of transported energy. Thus, their energy cost could be smaller. It may compensate for part of the greater construction costs. Nevertheless, it is assumed that the LH2 transportation cost is five times greater than for LNG transportation. According to [67], the LNG shipping cost is $0.04 €$ per kg-of-hydrogen-equivalent for a distance of $1,000 \mathrm{~km}$, thus the estimated cost for LH2 marine transportation is $0.20 € / \mathrm{kg}$.

A summary of the techno-economic data for option 3 is shown in Table 7. It appears that the energy cost of the delivered hydrogen would be in the range [60 - 69] $\mathrm{kWh} / \mathrm{kg}$ depending on the distance between the terminal and the customer. The corresponding energy efficiency range is [ $48-55 \%]$. The total cost range would be 4.1 to $4.9 € / \mathrm{kg}$ of delivered hydrogen depending on the distance to the terminal and pipeline. The transportation and distribution costs including compression and storage would account for 1.8 to $2.6 € / \mathrm{kg}$, i.e. $44 \%$ to $53 \%$ of the total cost. 


\begin{tabular}{|c|c|c|c|c|c|c|c|c|c|}
\hline \multirow[t]{2}{*}{ Vessel } & \multirow[t]{2}{*}{ Process stage } & \multicolumn{2}{|c|}{ Energy production } & \multicolumn{2}{|c|}{ Energy consumption } & \multirow{2}{*}{$\begin{array}{c}\text { Hydrogen losses } \\
\text { Longer term }\end{array}$} & \multicolumn{2}{|c|}{ Cost } & \multirow[t]{2}{*}{ Comments } \\
\hline & & Longer term & Unit & Longer term & Unit & & $\begin{array}{l}\text { Longer } \\
\text { term }\end{array}$ & Unit & \\
\hline $\begin{array}{l}\text { Offshore wind energy } \\
\text { converter }\end{array}$ & & 5,040 & kg/week & 60 & $\mathrm{kWh} / \mathrm{kg}$ & - & 3.4 & $€ / \mathrm{kWh}$ & Same as for Table 5 \\
\hline \multirow[t]{2}{*}{ Offshore Terminal } & $\begin{array}{l}\text { Offshore infrastructure } \\
\text { including offloading }\end{array}$ & 214 & tons/day & 0.5 & $\mathrm{kWh} / \mathrm{kg}$ & $1 \%$ & 0.11 & $€ / \mathrm{kg}$ & $\begin{array}{l}\text { 6\% losses during offloading operation } \\
\text { according to [55]. Assumes most of it is } \\
\text { recovered and re-liquefied. } \\
\text { Assumes costs similar to LNG terminal } \\
(1 \$ / \text { MMBtu, [67]) }\end{array}$ \\
\hline & Tank storage & 212 & tons/day & - & - & $1 \%$ & 0.02 & $€ / \mathrm{kg}$ & $\begin{array}{l}0.25 \% / \text { day for boil-off over } 4 \text { days. Costs } \\
\text { as for terminal in Table } 5 \text {. }\end{array}$ \\
\hline LH2 carrier & $\begin{array}{l}\text { Marine transportation } \\
\text { including loading }\end{array}$ & 210 & tons/day & - & - & $1.1 \%$ & 0.20 & $€ / \mathrm{kg}$ & $\begin{array}{l}0.5 \% \text { for loading and } 0.2 \% \text { day for boil- } \\
\text { off. Boil-off gas is used for powering the } \\
\text { ship. Assumes costs similar to highest data } \\
\text { for LNG transportation in [67] }\end{array}$ \\
\hline \multirow[t]{2}{*}{ Terminal } & $\begin{array}{l}\text { Infrastructure including } \\
\text { offloading }\end{array}$ & 208 & tons/day & - & - & $1 \%$ & 0.11 & $€ / \mathrm{kg}$ & $\begin{array}{l}\text { Same as for Table } 5 \text { except assumes } 1 \% \\
\text { losses thanks to greater cargo. }\end{array}$ \\
\hline & Tank storage & 206 & tons/day & - & - & $1 \%$ & 0.02 & $€ / \mathrm{kg}$ & $\begin{array}{l}\text { Same as for Table } 5 \text { except assumes } 4 \\
\text { days storage }\end{array}$ \\
\hline Subtotal & & 206 & tons/day & 63 & kWh/kg & $5 \%$ & 4.1 & $€ / \mathrm{kg}$ & \\
\hline Truck & & 3,323 & $\mathrm{~kg} / 2$ days & 1 & $\mathrm{kWh} / \mathrm{kg}$ & $6 \%$ & 0.56 & $€ / \mathrm{kg}$ & Same as for Table 5 \\
\hline Total & & 194 & tons/day & 69 & kWh/kg & $11 \%$ & 4.9 & $f / k g$ & \\
\hline
\end{tabular}

Table 7. Techno - economic data for option 3 for the production and distribution of hydrogen produced by far offshore wind energy converters. 


\begin{tabular}{|c|c|c|c|c|c|c|c|c|c|}
\hline \multirow[t]{2}{*}{ Vessel } & \multirow[t]{2}{*}{ Process stage } & \multicolumn{2}{|c|}{ Energy production } & \multicolumn{2}{|c|}{ Energy consumption } & \multirow{2}{*}{$\begin{array}{c}\text { Hydrogen losses } \\
\text { Longer term }\end{array}$} & \multicolumn{2}{|c|}{ Cost } & \multirow[t]{2}{*}{ Comments } \\
\hline & & Longer term & Unit & Longer term & Unit & & $\begin{array}{c}\text { Longer } \\
\text { term }\end{array}$ & Unit & \\
\hline $\begin{array}{l}\text { Offshore wind energy } \\
\text { converter }\end{array}$ & & 5,815 & $\mathrm{~kg} /$ week & 52 & $\mathrm{kWh} / \mathrm{kg}$ & $0.5 \%$ & 3.1 & $€ / \mathrm{kWh}$ & Same as for Table 6 \\
\hline \multirow[t]{2}{*}{ Offshore Terminal } & $\begin{array}{l}\text { Offshore infrastructure } \\
\text { including offloading }\end{array}$ & 247 & tons/day & - & - & $0.5 \%$ & 0.11 & $€ / \mathrm{kg}$ & $\begin{array}{l}0.5 \% \text { losses during offloading operation } \\
\text { according to [55]. } \\
\text { Assumes costs similar to LNG terminal } \\
\text { (1\$/MMBtu, [67]) }\end{array}$ \\
\hline & Tank storage & 247 & tons/day & - & - & - & 0.08 & $€ / \mathrm{kg}$ & Same as for Table 6 \\
\hline \multirow[t]{2}{*}{ CGH2 carrier } & $\begin{array}{l}\text { Compression to } 700 \text { bars } \\
\text { and loading }\end{array}$ & 246 & tons/day & 0.4 & $\mathrm{kWh} / \mathrm{kg}$ & $0,5 \%$ & 0.14 & $€ / \mathrm{kg}$ & $\begin{array}{l}\text { Energy consumption according to [54]. } \\
\text { Losses according to [55]. Costs estimates } \\
\text { according to [69]. }\end{array}$ \\
\hline & $\begin{array}{l}\text { Marine transportation } \\
\text { including loading }\end{array}$ & 246 & tons/day & 2.0 & $\mathrm{kWh} / \mathrm{kg}$ & - & 0.54 & $€ / \mathrm{kg}$ & See text in section 5.5 \\
\hline \multirow[t]{2}{*}{ Terminal } & $\begin{array}{l}\text { Infrastructure including } \\
\text { offloading }\end{array}$ & 244 & tons/day & - & - & $0.5 \%$ & 0.11 & $€ / \mathrm{kg}$ & Same as for Table 6 \\
\hline & Tank storage & 244 & tons/day & - & - & - & 0.08 & $€ / \mathrm{kg}$ & Same as for Table 6 \\
\hline Subtotal & & 244 & tons/day & 55 & $\mathrm{kWh} / \mathrm{kg}$ & $2.0 \%$ & 4.2 & f/kg & \\
\hline Pipeline & & 243 & tons/day & 0.9 & $\mathrm{kWh} / \mathrm{kg}$ & $0.5 \%$ & 0.24 & $€ / \mathrm{kg}$ & Same as for Table 6 \\
\hline Subtotal & & 243 & tons/day & 57 & $\mathrm{kWh} / \mathrm{kg}$ & $2.5 \%$ & 4.4 & f/kg & \\
\hline Truck & & 1,089 & $\mathrm{~kg} /$ day & 4.3 & $\mathrm{kWh} / \mathrm{kg}$ & $1.0 \%$ & 1.07 & $€ / \mathrm{kg}$ & Same as for Table 6 \\
\hline Total & & 218 & tons/day & 62 & kWh/kg & $3.5 \%$ & 5.5 & f/kg & \\
\hline
\end{tabular}

Table 8. Techno - economic data for option 4 for the production and distribution of hydrogen produced by far offshore wind energy converters. 


\subsection{Techno-economic analysis of option 4}

As for option 3, only the longer term is considered. The same techno-economic data as for option 2 is assumed for the wind energy converters, for truck delivery and for the on-shore terminal. For the data of the offshore terminal, it is simply assumed that it is the same as for the on-shore terminal. Therefore, the only missing techno-economic data is for the CHG2 carrier.

The storage pressure in the CGH2 carrier is assumed to be 700 bars (see section 5.1). As it has been assumed that the storage pressure is 350 bars at the offshore terminal, further compression is needed before loading the hydrogen onto the ship. The energy consumption is $0.4 \mathrm{kWh} / \mathrm{kg}$ for increasing the pressure from 350 to 700 bars according to [54]. The hydrogen loss is $0.5 \%$ [55]. The compression cost is estimated to be 0.14 $€ / \mathrm{kg}$ according to [69].

Cost and performance assessment of the $\mathrm{CGH} 2$ carrier is particularly challenging as no proposal for a CGH2 carrier has yet been made. Thus, estimates must be derived from available economic data for CNG carriers. According to [72], the CNG carrier capital cost is in the range of $200-900 \mathrm{M} \$ \mathrm{US}$ whereas it is in the range of $175-440 \mathrm{M} \$ \mathrm{US}$ for a LNG carrier. It is assumed that it is for the same amount of transported energy although it is not clearly stated in [72]. Therefore, the charter rate for a CNG carrier may be twice that of a LNG carrier. Moreover, according to [60], the energy that can be transported by a 7,000 tons displacement CNG carrier is approximately $6,750 \mathrm{MWh}$. In comparison, the displacement of a $120,000 \mathrm{~m}^{3}$ capacity LNG carrier carrying $720,000 \mathrm{MWh}$ is in the order of 90,000 tons. Thus, the ratio of transported energy to ship displacement appears to be 8 times greater for a LNG carrier than for a CNG carrier. The ship energy consumption being related to its displacement, the energy cost of a CNG carrier is also expected to be 8 times greater than for a LNG carrier. Thus, the transportation cost for a CNG carrier is expected to be 8 times that of a LNG carrier. According to [67], the LNG shipping cost is $0.04 €$ per kg-of-hydrogen-equivalent for a distance of $1,000 \mathrm{~km}$. Assuming that the shipping cost for a CNG carrier is 8 times that of a LNG carrier, a cost estimate is $0.32 € / \mathrm{kg}$. It is in agreement with [73] in which the shipping tariff is estimated to be $0.4 €$ per kg-of-hydrogen-equivalent for a distance (one-way) of $800 \mathrm{~km}$. Therefore, at $700 \mathrm{bar}$, the transported energy is extrapolated to be in the order of 5,050 MWh, i.e. 75\% that for CNG. Taking into account the lower capacity, the cost range is estimated to be 0.42 to $0.66 € / \mathrm{kg}$. The average of $0.54 € / \mathrm{kg}$ is finally retained.

Regarding energy consumption, the propulsion power for a 6,750 MWh CNG carrier is in the order of 4 MW [60]. The service speed is 14 knots. Thus, over a 2,000 km roundtrip, the energy consumption is $308 \mathrm{MWh}$. Assuming a cargo of 5,050 MWh of CGH2 (153 tons), the energy consumption is $2 \mathrm{kWh} / \mathrm{kg}$.

A summary of the techno-economic data for option 4 is shown in Table 8. It appears that the energy cost of the delivered hydrogen would be in the range [52 - 61] $\mathrm{kWh} / \mathrm{kg}$ depending on the distance between the terminal and the customer. The corresponding energy efficiency range is [54-63\%]. The total cost range would be 4.2 to $5.5 \mathrm{€} / \mathrm{kg}$ of delivered hydrogen depending on the distance to the terminal and pipeline. The transportation and distribution costs including compression and storage would account for 1.9 to $3.2 € / \mathrm{kg}$, i.e. $45 \%$ to $58 \%$ of the total cost.

\subsection{Discussion}

Figure 7 shows a comparison of the energy efficiency, hydrogen cost at terminal and delivered cost for transportation and distribution options 1 to 4 . It is 44 to $51 \%$ in the short term depending on the option. For the longer term, it is 48 to $56 \%$. Overall, it appears that significant energy losses occur during the energy storage and transportation processes. Also, the variations are rather small among the various options. Average longer term energy efficiency is $52 \%$. However, it appears that the options involving $\mathrm{CGH} 2$ are typically $6 \%$ more efficient than those involving LH2. Also, a similar pattern can be observed between options 1 and 3 and options 2 and 4: the energy efficiency increases by approximately 5\% in the longer term in comparison to the short term while marine transportation reduces efficiency by typically $2 \%$.

Regarding costs at the terminal and delivered costs, it must be acknowledged that they are expected to be high in the short term, in the range 6.6 to $8.7 € / \mathrm{kg}$ depending on the option and the delivery distance from the terminal. In the longer term, the cost range reduces to 3.3 to $5.5 € / \mathrm{kg}$. It is a $35-50 \%$ cost reduction. It mainly comes from the assumption that the cost of electricity produced aboard the wind energy converters could be 
halved from the short term to the longer term, with aboard electricity cost attaining $0.04 € / \mathrm{kWh}$ in the longer term.
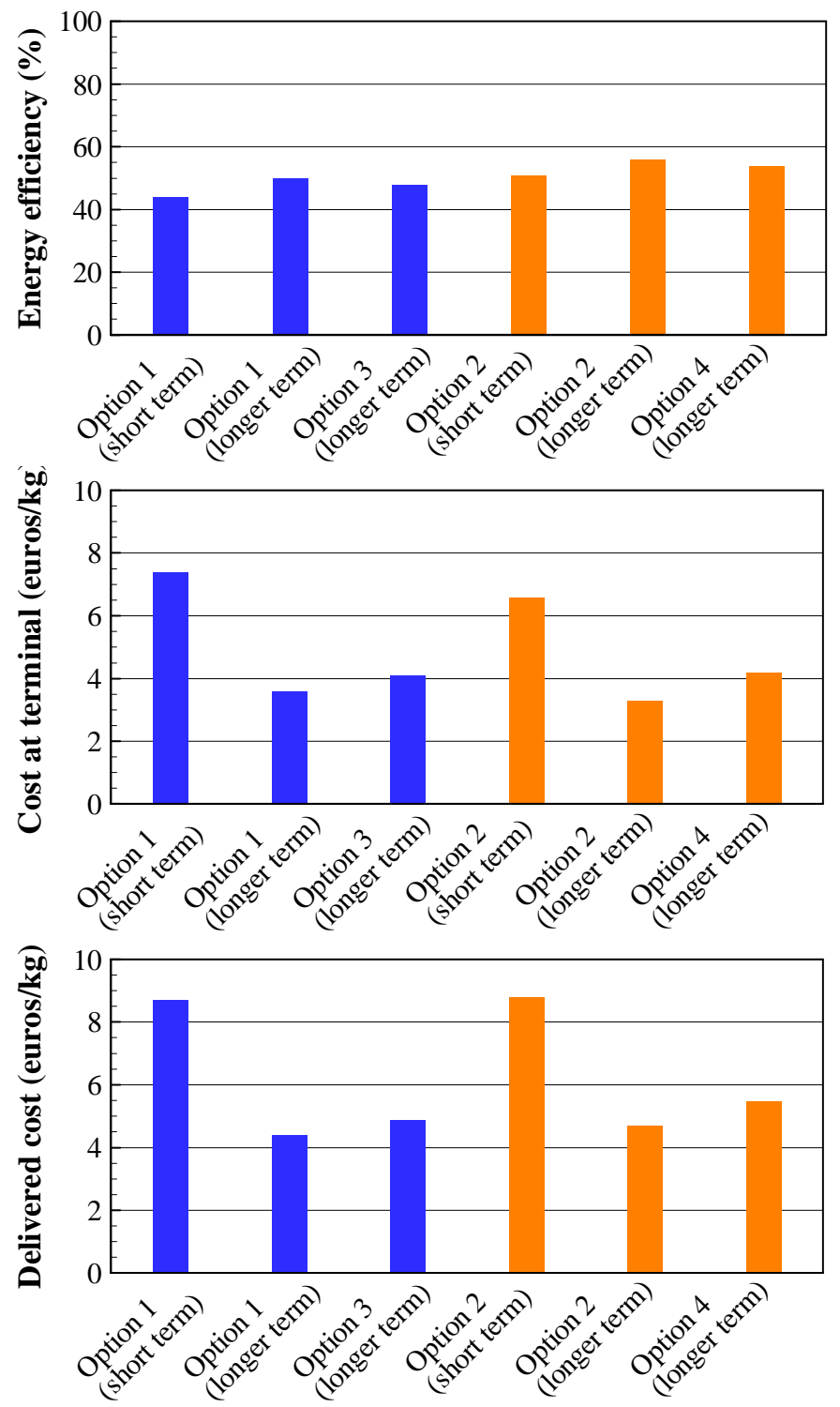

Figure 7 Comparison of energy efficiency, hydrogen cost at terminal and delivered cost for transportation and distribution options 1 to 4 . For options 1 and 2, a distinction is made between the short term potential and the longer term. For options 3 and 4, only the longer term is considered because those options involve hydrogen carriers that are not yet commercially available. The blue colour indicates that the transported fuel is $\mathrm{LH} 2$. The orange colour indicates $\mathrm{CGH} 2$.

Among the various options, option 2 has the least longer term cost at terminal $(3.3 € / \mathrm{kg})$ whereas option 1 has the least longer term delivered cost $(4.4 € / \mathrm{kg})$. Thus, although the CGH2 options are more energy efficient than the LH2 options, they involve systems with significantly higher cost for the hydrogen transportation and distribution which results in a higher total cost for the delivered hydrogen.

The costs being close, one may think that both options are equivalent. Actually, it appears that the LH2 options (options 1 and 3) are the most promising because the cost is much less sensitive for LH2 to the marine transportation distance or the distribution distance. For example, increasing the marine transportation distance from $1,000 \mathrm{~km}$ to $2,000 \mathrm{~km}$ would increase the cost by $0.2 € / \mathrm{kg}$ with $\mathrm{LH} 2(4.9 € / \mathrm{kg}$ to $5.1 € / \mathrm{kg}$ ) whereas the cost would increase by $0.54 € / \mathrm{kg}$ with CGH2 $(5.5$ to $6.1 € / \mathrm{kg})$. The doubling of the delivery distance $(600 \mathrm{~km}$ to $1,200 \mathrm{~km})$ in option 1 would increase the cost by $0.5 € / \mathrm{kg}(4.4$ to $4.9 € / \mathrm{kg})$ whereas it would increase by $0.9 € / \mathrm{kg}$ 
in option $2(4.7 € / \mathrm{kg}$ to $5.5 € / \mathrm{kg})$. Also a pipeline was assumed in the $\mathrm{CGH} 2$ options to optimize the distribution cost. Without the pipeline, the cost would be $0.6 € / \mathrm{kg}$ greater in the longer term option 2 . The pipeline is a capital intensive infrastructure which represents a significant financial risk. For example, what if the end-users at the end of the pipeline decide relocating their activities elsewhere? The LH2 options are more flexible as the trucks can obviously change destination as needed. Finally, LH2 storage tanks are much lighter than CGH2 storage tanks. They are also smaller. It is expected that these two characteristics can be advantageous for the wind energy converter performance. Indeed, a light converter would sail faster than a heavy converter. The apparent wind speed would also be greater. Thus, the absorbed wind energy which is proportional to the cube of the apparent wind speed could be significantly greater and thus energy cost could be smaller.
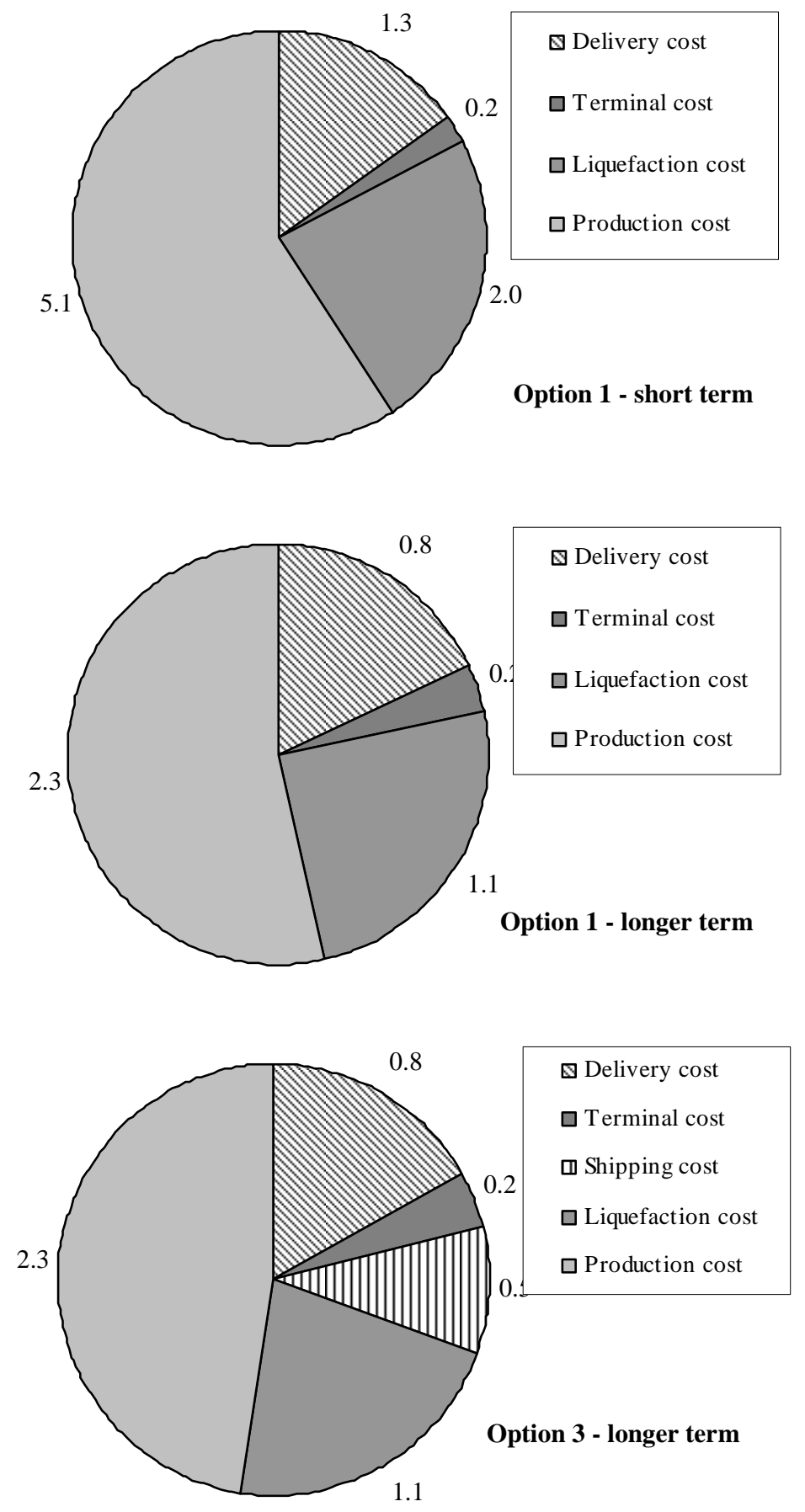

Figure 8 Cost breakdown for the production, transportation and delivery of hydrogen for option 1 for the short term (top chart), option 1 for the longer term (middle chart) and option 3 (bottom chart). 
Thus, from Figure 8 one can see that the production cost accounts for the majority of the costs in all options. Even though the share of the production cost reduces in the longer term in comparison to the short term, it is still approximately half of the total cost in the longer term.

Next is the liquefaction cost which accounts for approximately a quarter of the costs. Third is the delivery cost (approximately 15\%) for which one should recall that it strongly depends on the delivery distance. A $1,200 \mathrm{~km}$ round-trip is assumed for the data of Figure 8. Shorter or longer distances would change the share of the delivery cost. The fourth highest cost is the shipping cost for option $3(10 \%)$. Like for the delivery costs, it strongly depends on the distance. Finally, the terminal cost appears to be small.

Overall, it appears that the wind energy converter system cost (production cost and liquefaction costs) accounts for more than $80 \%$ of the total cost in option 1 for the short term, and approximately $75 \%$ of the total cost for the longer term options. The other costs are associated with transportation and distribution. It appears that they account for 5 to $23 \%$ of the total cost in options 1 and 14 to $30 \%$ of the costs in option 3 , depending on the distance of the end-user to the terminal.

The cost range for transportation and distribution is thus $0.2-1.5 € / \mathrm{kg}$. Obviously, it must not be higher than the market hydrogen price for economic feasibility. Fortunately, by comparing this cost range to the hydrogen price on the various markets in Figure 9, it can be observed that it is approximately 10 to $50 \%$ of the price depending on the market. Thus, the transportation and distribution cost does not seem to be a barrier to the economic feasibility of hydrogen produced by fleets of far offshore wind energy converters.

Moreover, note that most systems in the transportation and distribution chain are commercially available (trailers, storage, ...). Thus, the perspective for cost reduction for these systems is limited. Recalling that the wind energy conversion system cost accounts for approximately more than $80 \%$ in the shorter term and still $75 \%$ of the total cost in the longer term, it clearly appears that it is the wind energy conversion system on which to concentrate the research in order to achieve the most significant cost reductions.

Of course, there are many uncertainties on the longer term costs. Indeed, they rely on technical and economic assumptions that may not materialize. Therefore, it is worth assessing the robustness of the longer term cost estimates as a function of variations in the parameters.
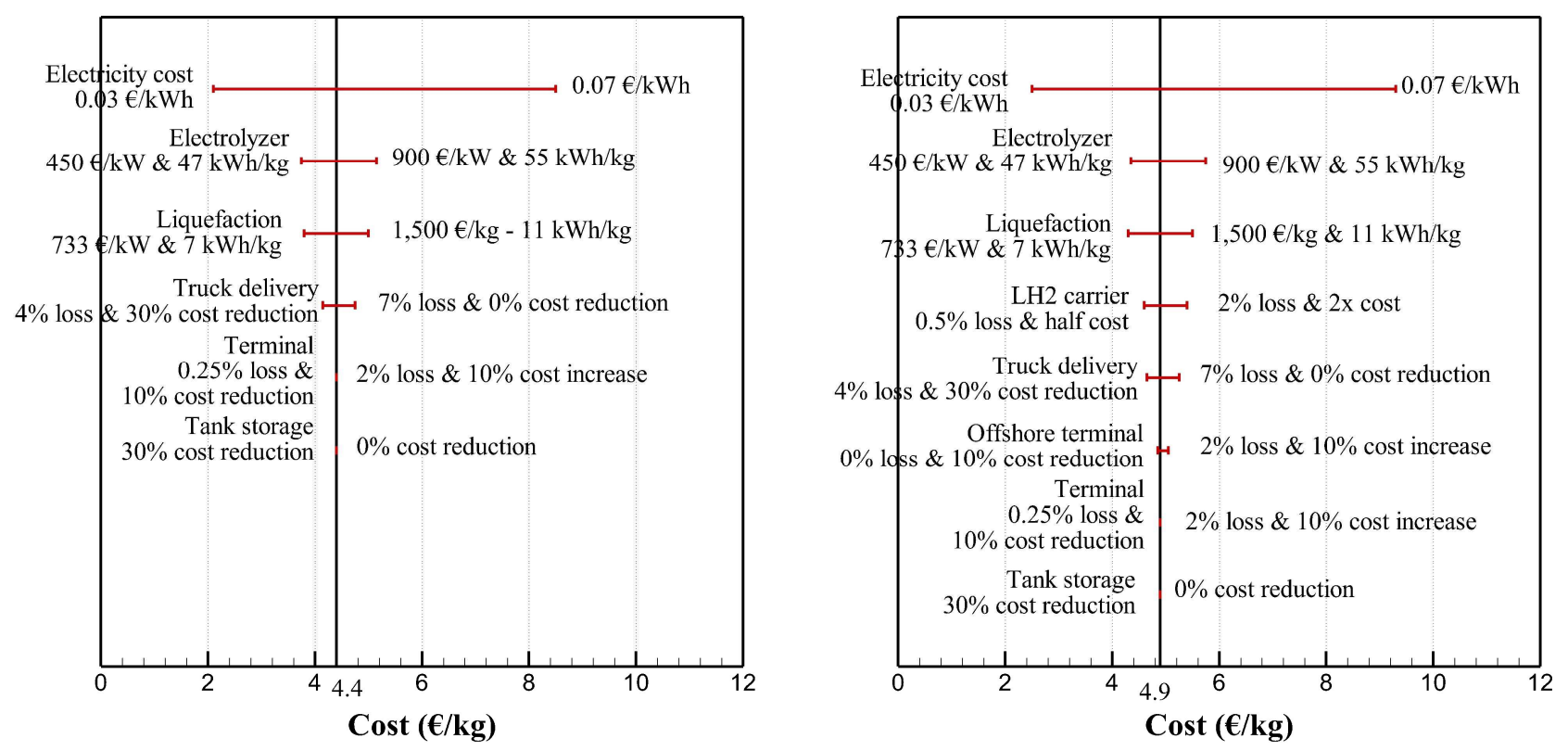

Figure 9 Cost sensitivities for longer term option 1 (left) and for option 3 (right)

Figure 9 shows the cost sensitivities for the principal variables studied. The electricity costs have by far the most impact in both options. . Electrolysis and liquefaction have the second and third greatest impacts in both options. The other costs appear to have much less impact on the total cost. This confirms that efforts 
should be focused on the wind energy converter for cost optimization. In addition, it indicates that the on-board electricity cost is the most important parameter to optimize.

Finally, let us compare the long term costs to the hydrogen prices in Table 2. It can be seen that there are several markets for which the hydrogen from fleets of far offshore wind energy converters could be competitive. They are the mobility/forklifts markets and the light industry market. The mobility/forklifts market volume is negligible in comparison to the light industry market. Despite being bigger, this last market is still relatively small. Indeed, using the energy efficiency of 50\% for option 1 in the longer term, it would take only one fleet of 300 wind energy converters of 2 MW power capacity to supply enough hydrogen for light industry use in Europe (80,000 tons). It is unlikely that the deployment of one fleet would be enough to bring cost down to the target of $0.04 € / \mathrm{kWh}$ for the aboard electricity cost in the longer term.

In the longer term, the hydrogen from fleets of far offshore wind energy converters can also be competitive on the isolated consumers market in some places. For this market, the hydrogen cost to consider is the cost at terminal because this market is expected to correspond to islandic communities. However, this market volume is unclear.

Another market on which the hydrogen could be competitive is the market of fuels for fuel cell vehicles. However, as discussed in section 4, this market is highly hypothetical. It may never develop because of the competition of electric vehicles.

Finally, competitiveness on the large industries market or injection in the gas grid would be the most challenging. Unfortunately, the hydrogen would not be competitive without further cost reductions or a support mechanism. A possible support mechanism is the carbon tax. Assuming that the end-users are co-located with the terminal, it would still require a minimum carbon tax of $200 € /$ ton to achieve parity with conventional hydrogen production based on the steam methane reforming process or for injection in the gas grid. In 2017, the carbon tax was $30 € /$ ton in France. It was $150 \$ /$ ton in Sweden. For France, it is expected to rise to $56 € / \mathrm{kg}$ in 2020 and to reach $100 € / \mathrm{kg}$ in 2030 .

\section{Conclusion}

In this paper, the techno-economic feasibility of fleets of far offshore hydrogen producing wind energy converters has been studied. The wind energy converters may be energy ships or sailing wind turbines.

Firstly, the resource has been estimated. It is found to be very large. Fleets of far offshore wind energy converters which would exploit $4 \%$ of the global ocean surface could produce enough energy to cover the forecasted 2050 global energy demand. It has also been found that approximately $30 \%$ of the best resource is located at less than $1,000 \mathrm{~km}$ from shore, thus actually not very far offshore. Some of this resource is located near to densely populated areas.

Far offshore wind energy converters cannot be grid-connected because of grid-connection costs. Thus, energy needs to be stored on-board. Hydrogen production and storage has been selected because it has one of the highest gravimetric energy density even when taking into account the mass of the storage tanks. Several market opportunities have been reviewed. Existing markets appear to be characterized either by large volume or high price.

Scenarios have been proposed for the exploitation of fleets of far offshore wind energy converters including transportation and distribution of the produced hydrogen. Half of the scenarios involve liquid hydrogen (LH2) whereas the other half involve compressed hydrogen (CGH2). It is noted that for the scenarios that don't involve marine transportation of hydrogen with dedicated carriers, all the systems involved except the wind energy converters are already commercially available.

Although the CGH2 scenarios have the best energy efficiency (up to $62 \%$ in the longer term), it is found that the cost estimates are close between the LH2 scenarios and the CGH2 scenarios. In the shorter term, delivered cost estimates are in the range 6.6 to $8.8 € / \mathrm{kg}$ depending on the option and the delivery. In the longer term, the cost estimates could reduce to 3.3 to $5.5 \mathrm{€} / \mathrm{kg}$. Although the cost estimates are close between the options, it is believed that the LH2 scenarios are the most promising in the longer term because of slightly smaller costs and much greater flexibility for delivery. 
The produced hydrogen could be competitive on the higher price markets in the longer term (light industry, isolated consumers). For the large volume low price (oil processing, ammonia production, injection on gas grids), support mechanisms such as the carbon tax are likely to be required unless further cost reductions can be achieved. Assuming that the longer term cost estimates can be realized and without further cost reductions, a carbon tax of $200 € / \mathrm{kg}$ would be required for competitiveness on these large industry high GHG emissions markets.

\section{Outlook}

The analysis of cost sensitivities shows that the main cost driver is the electricity cost aboard the wind energy converter. Results presented in this paper are highly dependent on the assumption that the electricity cost on-board the wind energy converters can reach $0.08 € / \mathrm{kWh}$ in the short term and $0.04 € / \mathrm{kWh}$ in the longer run, yielding delivered hydrogen prices of approximately $8 € / \mathrm{kg}$ and $4 € / \mathrm{kg}$, respectively. The recent multi-pole systems analysis published in [23] [24] estimated the levelized cost of hydrogen (LCOH) to be 13.9 and $10 € / \mathrm{kg}$, respectively. These estimates are likely to be very conservative because they are based on published cost data for manned ships designed for very different purposes. Moreover, they are for a ship that would be the first-of-akind. Experience from other renewable energy industries shows that cost can be reduced by 60 to $75 \%$ within one or two decades as the industry develops and installed capacity increases. Therefore it can be expected that unmanned autonomously operating displacement ships will approach the $\mathrm{LCOH}$ values derived in the present paper in the longer term.

Nevertheless, these values are still too high for entering the current largest hydrogen markets. Therefore the economic potential of far offshore wind energy conversion needs to be further assessed by concentrating on the following three areas:

- Improve the productivity of energy ships. It may be achieved by minimizing the ship hydrodynamic drag while maximizing the sail area and sail efficiency. This calls for the application of the most recent advances in aero-hydronautical engineering to the design of hydrofoil boats with highly efficient soft, or rigid wing sails, parawings or rotor sails in order to increase the boat speed to values approaching or even exceeding the wind speed. As is well known, the doubling of the boat speed produces an eight-fold increase in power output at the turbine.

- Investigate broaded economic and social benefits, for example accruing from the simultaneous production of electricity and potable water in drought-sensitive coastal areas. As shown in [64] [65], the reconversion of hydrogen into electricity in highly efficient power plants (for example, Graz cycle power plants described in [65]) yields significant amounts of water. For example, about $40 \%$ of the Australian households could be provided with water from the hydrogen power plants built to cover the electric power needs of the Australian industry [64]. Most of the Australian population lives near the coast, making it possible to eliminate any on-land hydrogen transportation costs. A further advantage arises from the fact that Australia is situated within the Class I wind area.

- Investigate the economic potential of storing the on-board electricity in electric vehicle (EV) batteries, thus making it possible to provide a steady supply of batteries for EV owners and for EV battery distributors. This mode of operating energy ships is likely to be economically viable only in coastal areas with sufficiently strong year-round winds. However, the use of highly efficient autonomously operating hydrofoil boats may open up Class II wind areas very close to the coast so that a once daily delivery of recharged batteries becomes feasible.

\section{Acknowledgements}

This research was partially supported by Agence de l'Environnement et de la Maitrise de l'Energie (ADEME) and Région Pays de la Loire through funding of the $\mathrm{PhD}$ project of M. Gaël Clodic. 


\section{References}

[1] Wind Europe. The European offshore wind industry: key trends and statistics 2016. Available at https://windeurope.org/wp-content/uploads/files/about-wind/statistics/WindEurope-Annual-OffshoreStatistics-2016.pdf Accessed on July, 27, 2017

[2] European Environment Agency. Europe's onshore and offshore wind energy potential: an assessment of environmental and economic constraints. EEA Technical report, No 6/2009.

[3] European Commission. Directorate-General for Energy. EU energy trends to 2030. Update 2009. Available at https://ec.europa.eu/energy/sites/ener/files/documents/trends_to_2030_update_2009.pdf. Accessed on July, 27, 2017

[4] D. Roddier, A. Peiffer, A. Aubault, C. Cermelli (2017) Summary and conclusions of the full life-cycle of Windfloat FOWT prototype project. In Proc. of the $36^{\text {th }}$ International Conference on Ocean, Offshore and Artic Engineering, Trondheim, Norway

[5] R. James, M. Costa Ros. (2015) Floating Offshore Wind: Market and technology review. Carbon Trust, June 2015. Available at https://www.carbontrust.com/media/670664/floating-offshore-wind-markettechnology-review.pdf

[6] http://www.bbc.com/news/business-40699979 Accessed on July, 27, 2017

[7] X. Lu, M.B. McElroy, J. Kiviluoma (2009) Global potential for wind-generated electricity. Proceedings of the National Academy of Sciences, Vol. 106(27), 10933-10938. doi:10.1073/pnas.0904101106

[8] A. Kitous, K. Keramidas, T. Vandysck. B. Saveyn (2016) GECO 2016. Global energy and climate outlook. Road from Paris. EUR 27952 EN. doi: 10.2791/662470

[9] Offshore wind programme board. Transmission costs for offshore wind. Final report, April 2016. Downloaded from https://ore.catapult.org.uk/wp-content/uploads/2016/05/Transmission-Costs-forOffshore-Wind.pdf

[10] H. Chen, T. Ngoc Cong, W. Yang, C. Tan, Y. Li, Y. Ding (2009) Progress in electrical energy storage system: a critical review. Progress in Natural Science, Vol. 19, pp. 291-312.

[11] R.E. Salomon (1982) Process of converting wind hydrogen to elemental hydrogen and apparatus therefor. U.S. Patent 4335093 A

[12] M. Meller (2006) Wind-power linear motion hydrogen production systems. U.S. Patent 7,146,918 B2

[13] A.R. Gizara (2007) Turbine-integrated hydrofoil. U.S. Patent 2007/0046028A1

[14] M. Tsujimoto, T. Uehiro, H. Esaki, T. Kinoshita, K. Takagi, S. Tanaka, H. Yamaguchi, H. Okamura, M. Satou, Y. Minami (2009) Optimum routing of a sailing wind farm. Journal of Marine and Science Technology, Vol. 14, pp. 89-103

[15] J. Kim, C. Park (2010) Wind power generation with a parawing on ships, a proposal. Energy, Vol. 35, pp. $1425-1432$

[16] M.F. Platzer, N. Sarigul-Klijn, J. Young, M.A. Ashraf, J.C.S. Lai (2014) Renewable hydrogen production using sailing ships. ASME Journal of Energy Resources Technology, Vol. 136 
[17] J.C. Gilloteaux, A. Babarit (2017) Preliminary design of a wind driven vessel dedicated to hydrogen production. In Proc. of the ASME $36^{\text {th }}$ International Conference on Ocean, Offshore and Artic Engineering (OMAE2017), Trondheim, Norway.

[18] http://www.energy-observer.org/

[19] D.B. Levin, R. Chahine (2010) Challenges for renewable hydrogen production from biomass. International Journal of Hydrogen Energy, Vol. 35, pp. 4962-4969

[20] Z. Ziaka, S. Vasileiadis (2013) Pretreated landfill gas conversion process via a catalytic membrane reactor for renewable combined fuel cell-power generation. Journal of Renewable Energy

[21] S. I. Allakhverdiev, V. Thavasi, V.D. Kreslavski, S.K. Zharmukhamedov, V.V. Klimov, S. Ramakrishna, D.A. Los, M. Mimuro, H. Nishihara, R. Carpentier (2010) Photosynthetic hydrogen production. Journal of Photochemistry and Photobiology C: Photochemistry Reviews. Vol. 11, pp. 101-113

[22] M. Mahdi Najafpour, S.I. Allakhverdiev (2012) Manganese compounds as water oxidizing catalysts for hydrogen production via water splitting: From manganese complexes to nano-sized manganese oxides. International Journal of Hydrogen Energy, Vol. 37, pp. 8753-8764

[23] M. Kopp, D. Coleman,C. Stiller, K. Scheffer, J. Aichinger, B. Scheppat (2017) Energiepark Mainz: Technical and economic analysis of the worldwide largest Power-to-Gas plant with PEM electrolysis. International Journal of Hydrogen Energy, Vol. 42, pp. 13311-13320

[24] G. Gahleitner (2013) Hydrogen from renewable electricity: an international review of power-to-gas pilot plants for stationary applications. International Journal of Hydrogen Energy, Vol. 38, pp. 2039-2061

[25] M. Kim, K. Kim (2017) An integrated decision support model for design and operation of a wind-based hydrogen supply system. International Journal of Hydrogen Energy, Vol. 42, pp. 3899-3915

[26] R. Loisel, L. Baranger, N. Chemouri, S. Spinu, S. Pardo (2015) Economic evaluation of hybrid off-shore wind power and hydrogen storage system. International Journal of Hydrogen Energy, Vol. 40, pp. 67276739

[27] J.C. Kim, C. Park (2014) Economy of hydrogen production by parafoil-pulled ships. Journal of Energy and Power Sources. Vol. 1(1), pp. 9-16

[28] M. Holl, L. Rausch, P.F. Pelz (2017) New methods for new systems - how to find the technoeconomically optimal hydrogen conversion system. International Journal of Hydrogen Energy 42, 22641-22654

[29] P.F. Pelz, M. Holl, M. Platzer (2016) Analytical method towards an optimal energetic and economical wind-energy converter. Energy Vol. 94, pp. 344-351

[30] V. Masson-Delmotte, H. Le Treut, D. Paillard (2013) Chapitre 2 : Energie, effet de serre et changement climatique. In «L'énergie à découvert», Eds R. Mosseri, C. Jeandel, CNRS Editions.

[31] https://x.company/makani/

[32] W.T. Liu, W. Tang, X. Xie (2008) Wind power distribution over the ocean. Geophysical research letters, Vol. 35 .

[33] International Electrotechnical Commission (2005) Wind turbines - Part 1: Design requirements. International standard IEC 61400-1 
[34] G. Sinden (2017) Characteristics of the UK wind resource: long-term patterns and relationship to electricity demand. Energy policy.

[35] https://worthingtonindustries.com/Products/Industrial-Gas/Industrial-Gas-Cryogenic-Vessels/Cryogenic$\underline{\text { ISO-Containers }}$

[36] J.L. Sloop (1978) Liquid hydrogen as a propulsion fuel. The NASA history series. NASA SP-4404

[37] M. Ball, M. Wietschel (2009) The future of hydrogen - opportunities and challenges. International Journal of Hydrogen Energy, Vol. 34, pp. 615-627

[38] International Energy Agency (2017) Global EV outlook 2017 - Two million and counting. Available at: https://www.iea.org/publications/freepublications/publication/GlobalEVOutlook2017.pdf

[39] L. Eudy, M. Post, M. Jeffers (2016) Fuel cell buses in U.S. transit fleets: current status 2016. National Renewable Energy Laboratory, Technical report NREL/TP-5400-67097

[40] C. Chardonnet, L. de Vos, F. Genoese, G. Roig, V. Giordano, S. Rapoport, F. Bart, T. De Lacroix, T. Ha, B. Van Genabet, J-C. Lanoix, W. Vanhoudt (2017) Study on early business cases for H2 in energy storage and more broadly power to $\mathrm{H} 2$ applications. Final report. A report by Tractebel and Hinicio. Funded by Fuell Cells and Hydrogen Joint Undertaking.

[41] S. Satyapal (2017) Hydrogen and fuel cells overview. Presentation, DLA Worldwide energy conference, National Harbor, MD, April 12, 2017. Available at: https://energy.gov/sites/prod/files/2017/06/f34/fctoh2-fc-overview-dla-worldwide-energy-conf-2017-satyapal.pdf

[42] L.L. Gaines, A. Elgowainy, M.Q. Wang (2008) Full fuel-cycle comparison of forklift propulsion systems. Argonne National Laboratory. Technical report ANL/ESD/08-3

[43] CRYOPLANE (2003). Final technical report. Project $n^{\circ}$ GDR1-1999-10014. Co-ordinator: Airbus Deutschland GmbH.

[44] C. Philibert (2017) Producing ammonia and fertilizers: new opportunites from renewables. Technical note of the International Energy Agency. Available at: https://www.iea.org/media/news/2017/FertilizermanufacturingRenewables_1605.pdf Accessed on July, 25,2017

[45] S. Wood and A. Cowie (2004) A review of greenhouse gas emission factor for fertiliser production. IEA Bioenergy Task 38.

[46] http://www.itm-power.com/news-item/10mw-refinery-hydrogen-project-with-shell

[47] M. Ball, M. Wietschel (2015) The hydrogen economy: opportunities and challenges. Cambridge University Press.

[48] http://ec.europa.eu/eurostat/statistics-explained/index.php/Electricity_price_statistics

[49] W. Sanz, M. Braun, H. Jericha, M.F. Platzer. Adapting the zero-emission Graz cycle for hydrogen combustion and investigation of its part load behaviour. International Journal of Hydrogen Energy. In Press

[50] https://www.wired.com/2017/04/toyotas-still-serious-hydrogen-built-semi-prove/

[51] http://www.powertogas.info/strategieplattform/strategieplattform.htm

[52] http://www.abc.net.au/news/2017-08-08/trial-to-inject-hydrogen-into-gas-lines/8782956 
[54] M. Gardiner, S. Satyapal (2009) Energy requirements for hydrogen gas compression and liquefaction as related to vehicle storage. DOE hydrogen and fuel cells program record. Record \#9013. Available at: https://www.hydrogen.energy.gov/pdfs/9013 energy requirements for hydrogen gas compression.pdf

[55] T-P. Chen (2008) Hydrogen delivery infrastructure options analysis. Nexant. Final report.

[56] S. Tamhankar (2014) Terminal operations for tube trailer and liquid tanker filling: status, challenges and R\&D needs. DOE hydrogen transmission and distribution workshop, Golden, CO, February 25-26, 2014

[57] D. Baldwin (2013) Bulk hauling equipment for CHG. Available at https://www1.eere.energy.gov/hydrogenandfuelcells/pdfs/csd_workshop_8_baldwin.pdf

[58] J. Ahn, H. You, J. Ryu, D. Chang (2017) Strategy for selecting an optimal propulsion system of a liquefied hydrogen tanker. International Journal of Hydrogen Energy, Vol. 42, pp. 5366-5380

[59] https://ww2.eagle.org/en/news/abs-outlook/2016/Launching_Worlds_First_CNG_Ship.html

[60] B. Putrajaya (2015) Compressed natural gas (CNG) shipping in Indonesia: opportunities ahead. $2^{\text {nd }}$ Small LNG shipping conference, Bali, Indonesia

[61] E. Beeker (2014) Y a-t-il une place pour l'hydrogène dans la transition énergétique ? La note d'analyse $\mathrm{n}^{\circ} 15$, France Stratégie, août 2014

[62] EE Consultant, HESPUL, SOLAGRO (2014) Etude portent sur l'hydrogène et la méthanation comme procédé de valorisation de l'électricité excédentaire. Rapport d'étude. Available at http://www.ademe.fr/etude-portant-lhydrogene-methanation-comme-procede-valorisation-lelectriciteexcedentaire

[63] M. Gotz, J. Lefebvre, F. Mors, A. McDaniel Koch, F. Graf, S. Bajohr, R. Reimert, T. Kolb (2016) Renewable Power-to-Gas: a technological and economic review. Renewable Energy, Vol. 85, pp. 13711390

[64] C. Chardonnet, L. De Vos, F. Genoese, G. Roig, V. Giordano, S. Rapoport, F. Bart, T. De Lacroix, T. Ha, B. Van Genabet, J-C. Lanoix, W. Vanhoudt (2017) Study on early business cases for H2 in energy storage and more broadly power to $\mathrm{H} 2$ applications. Tractebe \& Hinicio. Final report. Funded by Fuel cells and hydrogen joint undertaking

[65] C. Moné, M. Hand, M. Bolinger, J. Rand, D. Heimiller, J. Ho (2017) 2015 Cost of wind energy review. National Renewable Energy Laboratory, Technical Report NREL/TP-6A20-66861. Available at https://emp.lbl.gov/sites/default/files/2015_nrel_cost_of_wind_energy_review_lbnl.pdf

[66] M.F. Platzer, N. Sarigul-Klijn (2018) Carbon-neutral jet fuel production from seawater. International journal of sustainable aviation.

[67] V. Chandra (2006) Fundamentals of natural gas: an international perspective. Penwell

[68] H. Quack (2001) Die schüsselrole des kryogentechnick in des wasserstoff-energiewirtschaft. Wissenschaftliche zeitschrift der Technischen Universtität Dresden, 50 (5/6)

[69] G. Parks, R. Boyd, J. Cornish, R. Remick (2014) Hydrogen station compression, storage, and dispensing : technical status and costs. National Renewable Energy Laboratory, Technical Report NREL/BK-6A10-58564 
[70] H. Wang, D. Rutherford, C. Desai (2014) Long-term energy efficiency improvement for LNG carriers. Working paper 2014-8. The international council on clean transportation (ICCT)

[71] Propulsion of $7,000-10,000$ dwt small tanker. MAN. Available at http://marine.man.eu/docs/librariesprovider6/technical-papers/propulsion-of-7-000-10-000-dwt-smalltanker.pdf?sfvrsn=10

[72] C. Young, P. Eng (2007) Marine CNG: Technically sound, commercially viable, and imminent. In Proc. of the 2007 Offshore Technology Conference, Houston, Texas, USA

[73] Sea NG Alliance (2013). Delivers natural gas. Marine CNG Transportation. Platts Caribbean energy conference.

[74] [64] M.F. Platzer, M. Lennie, D.M. Vogt (2013) Analysis of the conversion of ocean wind power into hydrogen, Proc. World Renewable Energy Congress, Perth, Australia

[75] [65] M.F. Platzer, W. Sanz, H. Jericha (2014) Renewable power via energy ship and Graz cycle, ISROMAC-15 